\title{
Metodologické otázky srovnávací pedagogiky: podněty pro koncipování komparativních studií
}

\author{
Milada Rabušicová, Klára Záleská \\ Masarykova univerzita, Filozofická fakulta, Ústav pedagogických věd \\ Redakci zasláno 15. 2. 2016 / upravená verze obdržena 22. 6. 2016 / \\ k uveřejnění přijato 17. 8. 2016
}

\begin{abstract}
Abstrakt: Cílem je v kritickém přehledu zhodnotit metodologické postupy, jež se objevily ve srovnávací ${ }^{1}$ pedagogice $v$ průběhu jejího nedávného vývoje a jež jsou využívány aktuálně. Zdroje autorky hledaly převážně v zahraniční literatuře posledních dvou dekád. Metodologické otázky srovnávací pedagogiky se obvykle řeší v kategoriích účelů srovnávacích studií (deskripce, analýza, explanace, predikce), výzkumných paradigmat (kvalitativní, kvantitativní, kombinace), výzkumných designů (případové studie, large-scale surveys), různých teoretických a metodologických přístupů (pluralita metod a výzkumných technik), modelů komparace a šířky a hloubky záběru srovnávacích studií (lokální, regionální, globální), využívaných zdrojů (vlastní sběr dat, metaanalýza existujících dat, dokumenty), role výzkumníků a konečně jejich metodologických limitů. Účelem je poskytnout čtenáři obrázek o možných variantách, s nimiž může výzkumník vstupovat do designování své srovnávací studie, a to $\mathrm{v}$ některých případech i s př́klady již realizovaných srovnávacích výzkumů.
\end{abstract}

Klíčová slova: srovnávací/komparativní pedagogika, účely srovnávacích výzkumů, designy srovnávacích studií, prrípadová studie, large-scale surveys, metody sběru dat, modely komparace, lokalizace případů

Srovnávací pedagogika a mezinárodní studie o vzdělávání ${ }^{2}$ prožívají svoji renesanci. Podle Arnova (2013, s. 16) je to způsobeno především globalizací, která s sebou nese všudyprrítomnou potřebu učit se o sobě navzájem $\mathrm{s}$ takovou naléhavostí a důrazem jako nikdy předtím v historii. Postmoderní zpochybnění meta-narace a "totalizujícího diskurzu“ způsobila, že současné

\footnotetext{
$1 \quad$ Pojmy srovnávací a komparativní v textu užíváme jako synonyma.

2 Vymezení srovnávací a mezinárodní pedagogiky můžeme nalézt v textu Walterové (1993).
} 
bádání a praxe pochybuje téměř o všech dosud přijímaných nálezech a faktech. Autoři shrnují, že je-li pro srovnávací pedagogiku jako obor něco charakteristického, pak je to její neustále se měnící charakter.

\section{Jedna metoda neexistuje}

Od doby svého vzniku na akademické půdě prošla srovnávací pedagogika řadou změn vyplývajících z různého teoretického zakotvení: od modernizační teorie a strukturálního funkcionalismu přes neomarxismus, etnometodologii a etnografický přístup až po různé „post-ismy“ (poststrukturalismus, postmodernismus a další). Nový vývoj oboru zahrnuje, jak říkají autoři, také teorie multikulturalismu, sociálních hnutí, kritického modernismu (Arnove, 2013, s. 16) a neoinstitucionalismu (Wiseman \& Chase-Mayoral, 2013). Ale viděno pozitivně např. spolu s Hawkinsem (1998, in Crossley, 1999), k dosažení skutečně demokratického vzdělávání je nezbytné podporovat dialog mezi a např́íc různými perspektivami a akademickými komunitami po celém světě, což je také argument ve prospěch potřebnosti srovnávací pedagogiky.

Ve vztahu ke změnám v teoretických východiscích srovnávací pedagogiky je přítomná také dlouholetá debata o její metodologii. Autoři se shodují, že neexistuje jedna metoda srovnávací pedagogiky. Chabbott a Elliot (2001) tuto skutečnost zdůvodňují tím, že neexistuje jediný typ srovnávací studie, která by dokázala odpovědět na všechny otázky týkající se fungování vzdělávání v jiných zemích a toho, jak ho můžeme zlepšit v té své. Nejplodnější studie jsou podle nich ty, které kombinují více metodologických postupů. Přesto, nebo právě proto, že neexistuje jediný metodologický postup, na kterém by se dohodli všichni výzkumníci mezinárodního vzdělávání, je zde prostor pro zlepšování všech typů studií. Každý mezinárodní srovnávací výzkum by měl tedy prvky vedoucí k precizaci výzkumné metodologie zahrnovat.

První tezí, o kterou se můžeme v našem výkladu opřít, je nemožnost existence pouze jednoho metodologického postupu. Phillips a Schweisfurthová (2008) to interpretují tak, že oblast zájmu srovnávací pedagogiky zahrnuje pestrou škálu témat a výzkumných př́ístupů, a nemůže proto existovat jeden model srovnávání, jenž by mohl být používán generálně ve všech srovnávacích studiích. Autoři tvrdí, že by se výzkumníci měli pokoušet produkovat systémový rámec pro analýzu, který používá Beredayův srovnávací model (Bereday, 1964) nazvaný juxtapozice, tedy vzájemné srovnávání údajů (bližší výklad dále), a který zahrnuje při jakémkoli pokusu o zobecnění výsledků vždy komplexní posouzení kontextu. 
Druhou tezí je, že i při neexistenci jednoho vhodného metodologického postupu, který by se dal aplikovat na všechny srovnávací pedagogické studie, je zde prostor pro zlepšování jednotlivých prvků, jež metodologii srovnávací pedagogiky tvoří. Řada studií, které se označují jako komparativní, totiž často nejednoznačně popisuje metodologii a nezdůvodňuje patřičně výběr případů. Nedávno také Vlček (2015, s. 395) kritizoval nedostatečnost v popisu metodologie a koncipování dnešních srovnávacích studií obecně. Opírá se o Manzonovou (2007) a Walterovou (2006), když tvrdí, že:

Jedním z českých i zahraničních specifik je, že metodologický diskurs není rozvíjen systematicky a i přes svou rozsáhlou poznatkovou základnu vykazují texty některých autorů určité z pohledu moderní pedagogické komparatistiky problémové rysy. Rukopisy bývají z velké části deskriptivní, mají často narativní charakter, postrádají explanace, hledání a navrhování řešení. Různá míra autorské zkušenosti často způsobuje např́iklad to, že svým rozsahem objemné studie prezentují v časopisech, a zejména na konferencích málo podložené a ověřené výsledky srovnávacího výzkumu. Někteří autoři se $v$ kapitole o použité metodologii více či méně omezí na informaci, že jako metoda vědeckého zkoumání byla použita metoda srovnávání. (Vlček, 2015)

S touto kritikou zcela souhlasíme, a právě proto přicházíme s pokusem tuto metodologickou neujasněnost alespoň částečně zprůhlednit. Nikoli ve smyslu hledání něčeho univerzálního a nejlepšího, což ani není možné, ale ve smyslu jisté rekapitulace toho, co různí renomovaní komparativisté nabízejí a co by mohlo být k užitku českým výzkumníkům při koncipování jejich srovnávací studie. Činíme tak s vědomím, že se nejedná jen o různorodost metodologických postupů, ale také o různorodost terminologickou podle toho, jak s jednotlivými pojmy pracují autoři, z jejichž textů vycházíme. Pro nás je zastřešujícím pojmem „metodologický postup“, respektive metodologie srovnávací studie. $V$ tomto rámci se pak objevují dílčí pojmy - komponenty metodologického postupu, jako je výzkumné paradigma, výzkumný design, metody sběru dat, metody analýzy dat a modely samotné komparace.

Článek je koncipován jako kritický přehled metodologických postupů (Mareš, 2013), přičemž si klademe otázku, jaké výzkumné postupy a jejich dílčí komponenty se používají při srovnávání pedagogických jevů. Uvádíme, které kroky může komparativista při navrhování svého výzkumného projektu zvažovat a jak by mohl postupovat, aby jeho práce byla kvalitní srovnávací studií. Při koncipování komparativní studie by totiž měl v hierarchickém sledu provést několik voleb: volbu typu studie podle jejího účelu (cíle), volbu výzkumného paradigmatu a výzkumného designu, volbu modelu samotného 
komparativního postupu, rozhodnutí o lokalizaci výzkumu, volbu o výběru a počtu jednotek analýzy, čímž je dána širŕka a hloubka analýzy dat, a konečně uvědomění si vlastní výzkumnické pozice a jejích limitů. $V$ těchto sekvencích jsou organizovány jednotlivé části této přehledové studie.

\section{Typy komparativních studií podle účelu}

Každé výzkumníkem zvolené téma je třeba metodologicky uchopit na základě zvážení povahy zkoumaného problému, a to v souvislosti s účelem srovnávací studie. Isaac Kandel (1936) ve své klasické práci Comparative Education tvrdil, že metodologie srovnávací pedagogiky je determinovaná právě účelem, ke kterému je daná studie určena (in Rust, Johnstone, \& Allaf, 2009, s. 129).

Později také Phillips a Schweisfurthová (2008) upozorňovali na důležitost účelu ve vztahu k volbě metodologického postupu srovnávací studie. Při argumentaci se obrací ke Kandelovi jako „otci zakladateli“ a tvrdí, že komparace vzdělávacích systémů několika zemí vede vždy k různorodosti použité metodologie závislé na tom, co je účelem, respektive cílem srovnávání.

$\mathrm{V}$ obecné rovině, a vlastně ve shodě s členěním jiných společenskovědních výzkumů, formulovali Theisen a Adams (1990) čtyři klasické typy srovnávacích studií podle jejich účelu. Na jejich typologii odkazuje později například Phillips (2006) - viz tabulka 1.

Konkrétněji, v přímém vztahu ke studiím srovnávací pedagogiky uvádějí Chabbott a Elliot (2001, s. 14) tři typy studií podle primárního účelu. Jejich členění je následující:

1) studie běžně obsahující large-scale výzkumy směřující ke srovnávání vzdělávacích výsledků ve dvou nebo více státech na různých úrovních (typicky TIMSS, PISA, standardizované testy ve více zemích);

2) studie určené k informování aktérů vzdělávací politiky, zaměřené na specifická témata relevantní pro tu kterou politiku a implementaci v jiných státech (např. Singapore Mathematics Curriculum Study);

3) studie, které nebyly vytvořeny primárně k přímému srovnávání mezi dvěma státy z hlediska vzdělávací politiky a vzdělávacích výsledků, ale jejich cílem je hlouběji pochopit pedagogické jevy a procesy v různých kulturních a národních kontextech. 
Tabulka 1

Typologie komparativních výzkumů podle účelu

\begin{tabular}{lll}
\hline \multicolumn{3}{c}{ Kritéria pro klasifikaci komparativního výzkumu podle jeho účelu } \\
\hline Typ výzkumu & Typické otázky & Účel výzkumu \\
\hline Analytický & Jaká jsou vysvětlení vztahů mezi & Popis a analýza rolí. \\
& komponentami? & Specifikace př́ćinných vztahů \\
& Proč se aktéři daného procesu chovají tak, & mezi zkoumanými fenomény \\
& jak se chovají? & či vysvětlení jejich vztahů \\
& Proč jisté systémy fungují tak, jak fungují? & a důsledků. \\
\hline Deskriptivní & Jaký je současný stav daného fenoménu? & Deskripce fenoménu. \\
& Jaký je vztah mezi proměnnými? & Deskripce vztahů mezi \\
& & proměnnými. \\
\hline \multirow{2}{*}{ Evaluační } & Je program A lepší nebo ekonomicky & Zhodnocení př́nosu a hodnot \\
& efektivnější než program B? & určitého programu či politiky. \\
& Odpovídá daný program nebo politika & Interpretace užitečné pro \\
& danému kontextu? & rozhodovací procesy. \\
\hline Explorační & Jaké oblasti týkající se existujících rolí, & Generování nových hypotéz \\
& vztahů a procesů jsou vhodné pro hodnocení & nebo otázek. \\
& ostatními výzkumníky? & Explorace vztahů a funkcí \\
& Jaké modely, paradigmata nebo metody & mezi určitými fenomény \\
& mohou být užitečné při navrhování & s potenciálem hloubkového \\
& budoucího výzkumu? & výzkumu. \\
\hline
\end{tabular}

Pozn.: Zpracováno podle Theisena a Adamse (1990) a Phillipse (2006).

K účelům srovnávacích studií se vyjadřuje také celá řada dalších autorů, a to v dlouhodobé perspektivě. Např. King (1967) ve své době viděl roli srovnávací pedagogiky v tom, že její studie ukazují, které instituce, myšlenky nebo postupy mohou být přenositelné $\mathrm{z}$ jednoho kontextu do jiného a co je relevantní ryze pro jeden kontext.

Přímo o „vypůjčování si fungujících praxí z cizího prostředí a jejich přenášení do vlastního kulturního prostředí jako o hlavním účelu srovnávací pedagogiky se nebojí uvažovat Phillips a Schweisfurthová (2008, s. 97). Způsoby, jakými lze přenášet vzdělávací postupy a praxi z jedné země do druhé, označují jako policy borrowing. Toto „vypůjčování“ obsahuje čtyři kroky: (1) zajímavosti napříc národy (cross-national attraction), (2) rozhodovací procesy (decision making procedure), (3) přijetí implementace určité politiky (adoption of particular policy implementation) a (4) zvnitřnění/zdomácnění politiky $\mathrm{v}$ rámci vlastního systému (internalization/indigenization). Tento model nemá být brán jako schéma pro analýzu, ale jako pomůcka 
komparativistům, kteří chtějí formulovat jasné sekvenční stupně svého postupu, chtějí podtrhnout důležitost kontextu ve srovnávací studii, chtějí navrhnout faktory, které mají být v každém stupni srovnávání zkoumány, a chtějí vytvořit představu o propojenosti sledovaných procesů.

Šířeji vidí účel srovnávacích studií např. Watsonová (2001, s. 30), když ř́ká, že základním úkolem je poskytnout vhled do procesu utváření politik (policy-making). Podobně Arnove (2013, s. 1) označují za hlavní účel komparativní pedagogiky poskytnutí podnětů relevantních pro pochopení společných problémů a regionálních, národních či místních rozdílů, kterým běžně čelí vzdělávací politika a praxe.

Vedle akcentu na „vypůjčování“ postupů z různých jiných systémů je často podtrhován moment ovlivňování do budoucnosti. Např. Phillips (2006, s. 309; Phillips \& Schweisfurth, 2008, s. 83) hovoří o tom, že srovnávací výzkum by měl být spojen s hledáním vhodnosti a realizovatelnosti zavádění nových opatření, která umožní předvídat další vývoj. Účelem srovnávacích studií je proto podle těchto autorů predikce budoucnosti. S tím se ztotožňuje i Watsonová (2001), která ř́ká, že účelem srovnávací pedagogiky není jen porovnávat současný stav vzdělávacích systémů, ale také navrhovat takové reformy, které nejlépe odpovídají novým sociálním a ekonomickým podmínkám.

Přínosem srovnávací pedagogiky je podle Rusta (2003) především to, že se dívá do budoucnosti. Později dodal, že účelem srovnávací pedagogiky je přispívat k možnosti využití výzkumných nálezů novou generací, která je může (a měla by) využívat ve jménu mezinárodního míru a sociální spravedlnosti v neustále se propojujícím a sbližujícím světě (Rust, Johnstone, \& Allaf, 2009, s. 134). Aby mohla hrát srovnávací pedagogika tuto náročnou roli, je ovšem potřeba, jak říká Rust, aby se vracela ke svým kořenům, k výzkumníkům jako je Kandel (1936), pro něhož zahrnutí politického, sociálního, ekonomického a kulturního kontextu do srovnávacích studií bylo stěžejní.

V zásadě by se tedy dalo shrnout, byt' je to různými autory formulováno různě, že hlavním účelem srovnávacích studií je poučit se (a poučit jiné, především aktéry rozhodování ve vzdělávací politice) o tom, jakým způsobem se řeší problémy vzdělávání v různých společnostech, kulturách, případně zemích, a kvalifikovaně odhadovat možnost přenositelnosti zjištěných postupů a řešení s ohledem na politický, kulturní, sociální a ekonomický kontext srovnávaných prostředí. A to vše nikoli pouze s ohledem na současnost, ale především na budoucnost. To je účel, který považujeme za vysoce relevantní také pro naši domácí situaci. 


\section{$3 \quad$ Paradigmata srovnávací pedagogiky}

Vyjasní-li si výzkumník účel své studie, potom by jeho dalším krokem měla být úvaha o designu srovnávací studie odvozeném od paradigmat, které srovnávací pedagogika nabízí. Tou základní obecnou volbou na základě vybraného problému a účelu studie je výzkumné paradigma založené na kvantitativním přístupu, kvalitativním př́istupu nebo na jejich kombinaci. Řada autorů (Lor, 2011; Rust, 2009) této otázce věnuje značnou pozornost, ale jejich výklady jsou v principu shodné s obecnou metodologickou diskusí probíhající také v rámci jiných společenských věd. Obdobná diskuse se vede i v souvislosti s epistemologií srovnávací pedagogiky, kterou je také potřeba zohlednit, a na jejímž základě se připomínají jak pozitivistické tradice ve srovnávacích studiích, tak „novější interpretativní paradigmata (Khakpour, 2012; Dash, 2005; Marginson \& Mollis, 2001).

V tabulce 2 uvádíme pro inspiraci Khakpourovu (2012) tabulku ${ }^{3}$ s příklady realizovaných srovnávacích výzkumů s odpovídajícími výzkumnými paradigmaty a použitými výzkumnými designy.

V obecnější rovině předznamenávají volbu výzkumného paradigmatu principiální myšlenkové postupy, jež má autor záměr použít. Opět se jedná o diskusi částečně paralelní s jinými společenskovědními obory, částečně specifickou pro srovnávací pedagogiku v jejím vývoji. Debata o tom, zda jít induktivní či deduktivní cestou, vznikla v době, kdy komparativní pedagogika začala hledat své silnější vědecké základy (Rust, 2003). Jako historicky první byl ve srovnávací pedagogice rozvíjen induktivní postup a jeho zastánci, zakladatelé", byli Kandel, Hans a Berreday v šedesátých letech minulého století. ${ }^{4}$ Deduktivní škola je ve srovnávací pedagogice reprezentována především Holmesem s jeho metodou řešení problému

3 Jedná se o autorský přehled, jenž je ovšem přeložen do češtiny s upravenými názvy metodologických pojmů tak, aby byly sourodé s celým textem. To, co podle našeho úzu označujeme jako výzkumný design, nazývá Khakpour výzkumnou metodou.

4 Isaac Kandel jako průkopník historického přístupu v komparativní pedagogice vycházel jasně z induktivní školy a jeho doporučované kroky při stavbě komparativní studie byly identifikace problému (nejprve deskripce zkoumaného problému v rámci historické perspektivy), explanace a interpretace (analýza příčin dané situace $\mathrm{z}$ hlediska sociálního, politického a kulturního), komparativní analýza (zaznamenání podobností a rozdílností ve zkoumaných entitách) a formulace zásad a tvorba vzdělávací filozofie jako poslední krok (Musa \& Agbaire Jomafuvwe, 2013, s. 352-353). 
(problem-solving) $^{5}$. Zatímco Kandelův induktivní postup nejprve zjišt’uje fakta a potom je analyzuje, pro Holmese je hlavní síla srovnávací studie v predikci: fakta jsou daná, ale predikce nevychází jen z předchozích příčin, nýbrž zahrnuje dedukci na základě nových informací získaných studiem zákonů a opatření ve specifických původních podmínkách. Podstatné ovšem je, že oba postupy, jak Kandelův, tak Holmesův, jsou orientovány reformně - to znamená, že mají přispívat ke změně nějakého pedagogického jevu či vzdělávací politiky.

Součástí diskuse je také téma diachronní či synchronní perspektivy ve srovnávacích studiích. Sweeting (2005) vychází z premisy, že srovnávací pedagogika a historie vzdělávání se vzájemně doplňují. Historická dimenze přidává další úroveň komplexity, která vyžaduje zvláštní znalosti při vyhledávání, hodnocení a využívání primárních zdrojů, a to jak v kvalitativních studiích, kde je historická perspektiva klíčovým komponentem při detailním popisu, tak v kvantitativních srovnávacích studiích (Lor, 2001, s. 16-17). Více informací o časové dimenzi ve srovnávacích studiích lze najít u Penningse, Kemana a Kleinnijenhuise (1999), kde je diskutována role místa a času a výzkumné designy jsou rozlišovány podle toho, zda jsou situované pouze do jedné časové dimenze, nebo sledují daný jev v průběhu času.

5 První fází srovnávací studie je podle Holmese, shodně s Kandelem, volba a deskripce problému. Problém je vybírán s předpokladem, že je běžný ve vzdělávacích systémech $\mathrm{v}$ různých částech světa a že může být objasněn a případně řešen prostřednictvím mezikulturního (cross-cultural) srovnání. Dalším krokem je tvorba hypotéz. Holmesův druhý krok zahrnuje - na rozdíl od Kandela - identifikaci několika praktických politických alternativ, které mohou být řešením daného problému. Aby tak mohl výzkumník učinit, musí nahlédnout na praktiky jiných států, které použije jako referenční body. Třetím krokem je specifikace původních podmínek nebo kontextů. Tento krok se podobá Kandelově explanaci a interpretaci. Do této fáze Holmes zahrnuje deskripci s připojením politického, sociálního, ekonomického, náboženského a kulturního kontextu. Předposlední krok nazývá logickým promítnutím přijatých hypotéz. Jelikož je výzkumník již obeznámen s kontextem, ve kterém se problém odehrává, je schopen nastínit výsledky možných řešení, které uvedl v hypotézách. Úkolem komparativisty je podle Holmese předvídat praktické dopady zaváděných politických opatření. Posledním, pátým, krokem je komparace logicky predikovaných dopadů/výsledků s pozorovatelnými událostmi. Výzkumník tedy testuje zformulované hypotézy (Musa \& Agbaire Jomafuvwe, 2013, s. 353). 


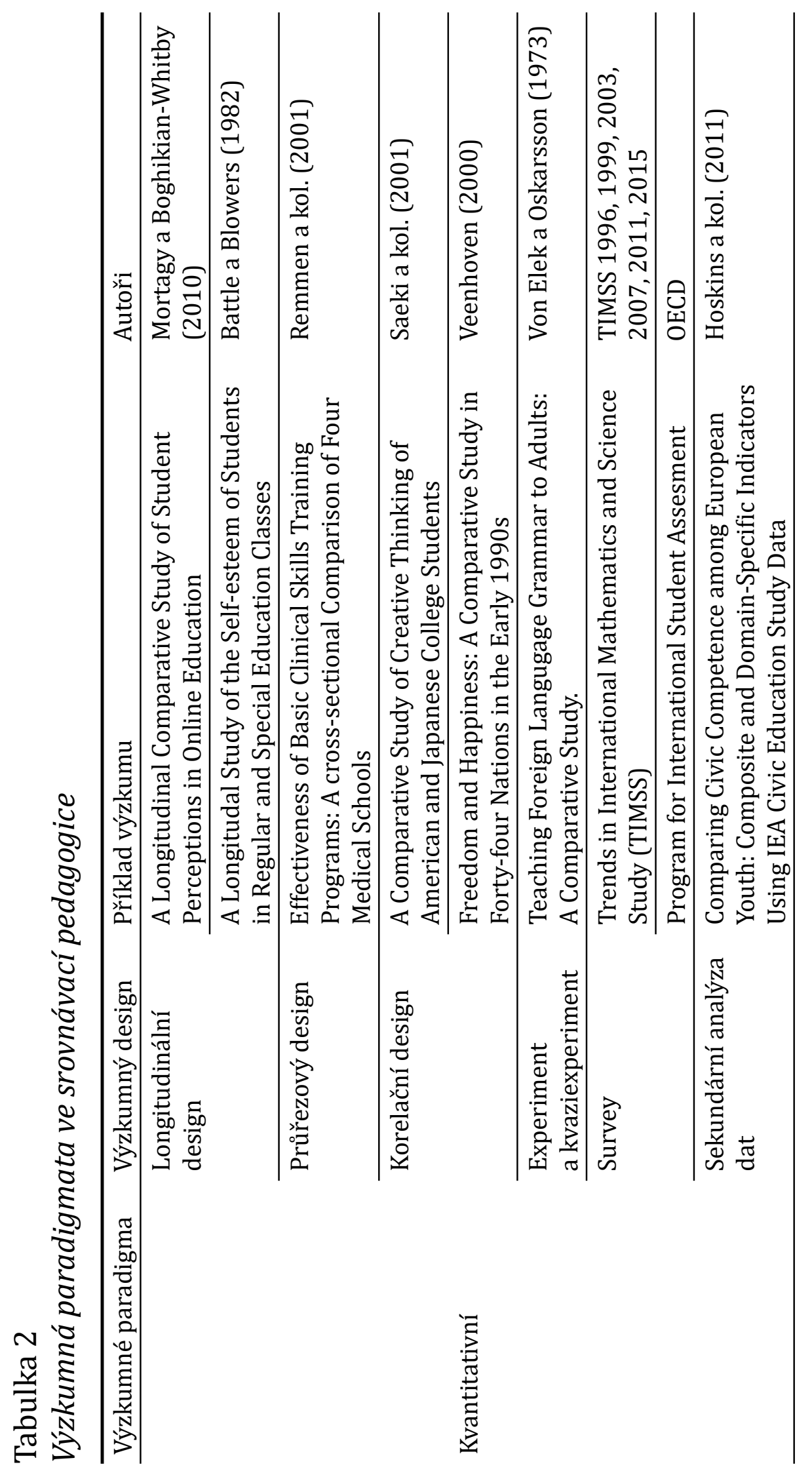




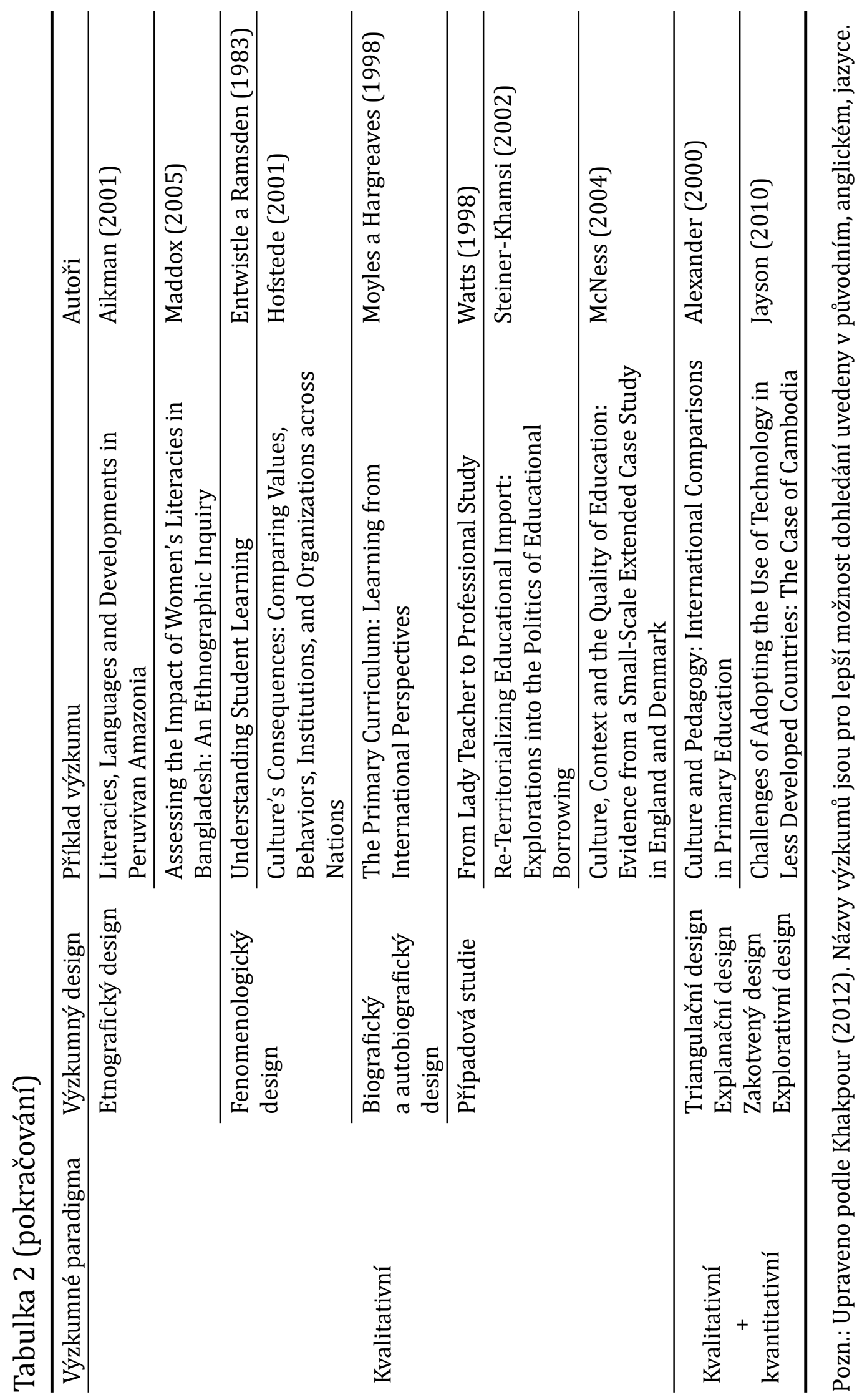




\section{Designy srovnávacích výzkumů}

Z předcházející Khakpourovy tabulky s přehledem výzkumných paradigmat a jim odpovídajících výzkumných designů vybíráme dva nejběžnější designy dnešní srovnávací pedagogiky. Jsou jimi srovnávací př́padové studie a tzv. large-scale surveys.

\subsection{Srovnávací prípadová studie}

S oporou o charakteristiku srovnávací prrípadové studie, jak ji poskytuje Goodricková (2014), můžeme říci, že taková studie zahrnuje dva nebo více př́padů způsobem, který zakládá na možnosti zobecnit poznatky o kauzálních otázkách, tedy jak a proč určité programy nebo politika fungují či nefungují. Srovnávací př́padovou studii je vhodné zvolit, jestliže se objevuje aktuální potřeba pochopit, vysvětlit a ovlivnit úspěch nějakého programu nebo politické iniciativy. Zahrnuje analýzu a syntézu shod, odlišností a vzorů napříč dvěma nebo více případy, které mají stejné zaměření nebo stejný cíl. Aby byl design srovnávací př́ípadové studie proveden správně a důkladně, měly by být specifické rysy každého př́ipadu na začátku studie detailně popsány. Studie často zahrnují jak kvantitativní, tak kvalitativní data. Dominují metody jako práce v terénu, pozorování, rozhovory a analýza dokumentů. Způsoby sběru dat jsou podobné jako u jednopř́ípadových studií, ale vícečetné případové srovnávací studie vyžadují rozsáhlejší koncepční, analytickou a syntetizující práci.

Jak při použití designu srovnávací případové studie postupovat? Návrh v šesti krocích ukazuje obrázek 1.

Kdy je vhodné zvolit tento výzkumný design? 0 srovnávací případové studii primárně jako o evaluačním výzkumu uvažuje Goodricková (2014), přičemž považuje za vhodné ji použít zejména v případech, (1) kdy pro výzkumníka otázky jak a proč představují základ porozumění procesům nebo výsledkům intervence; (2) pokud se implementuje intervence např́íč více kontexty a je zde malá nebo žádná př́ležitost řídit nebo kontrolovat způsob, jakým je implementována; (3) když má výzkumník př́ležitost pro opakovaný sběr dat a analýzu v průběhu zavádění intervence; (4) když se pochopení kontextu jeví jako klíčové pro pochopení úspěchu či neúspěchu intervence nebo (5) když experimentální a/nebo kvazi-experimentální designy nejsou z praktických či etických důvodů proveditelné. 
1 Vyjasnit si účel studie s cílem obhájit, že zvolený design je pro danou situaci vhodný.
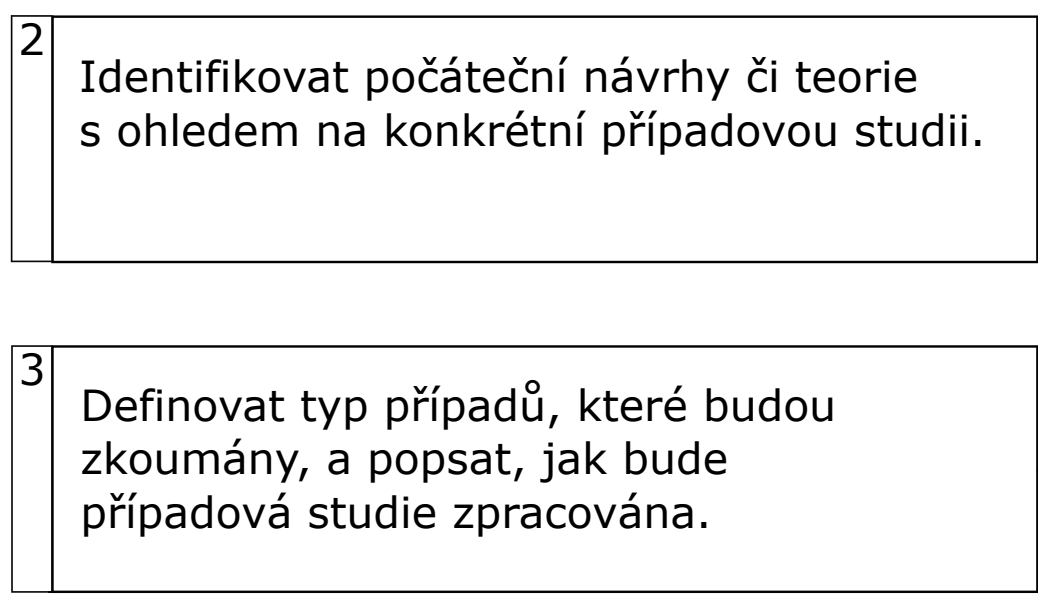

Nové př́ipady

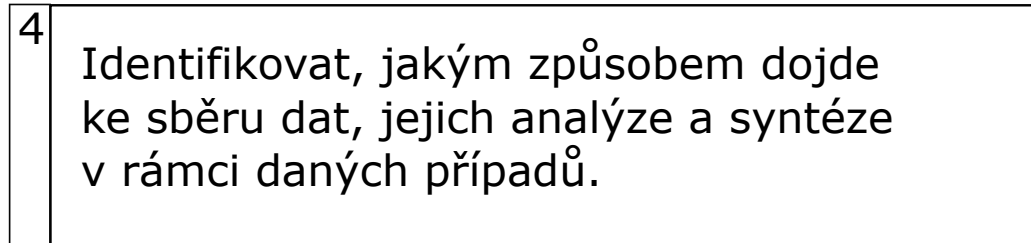

Nová data o existujících př́padech
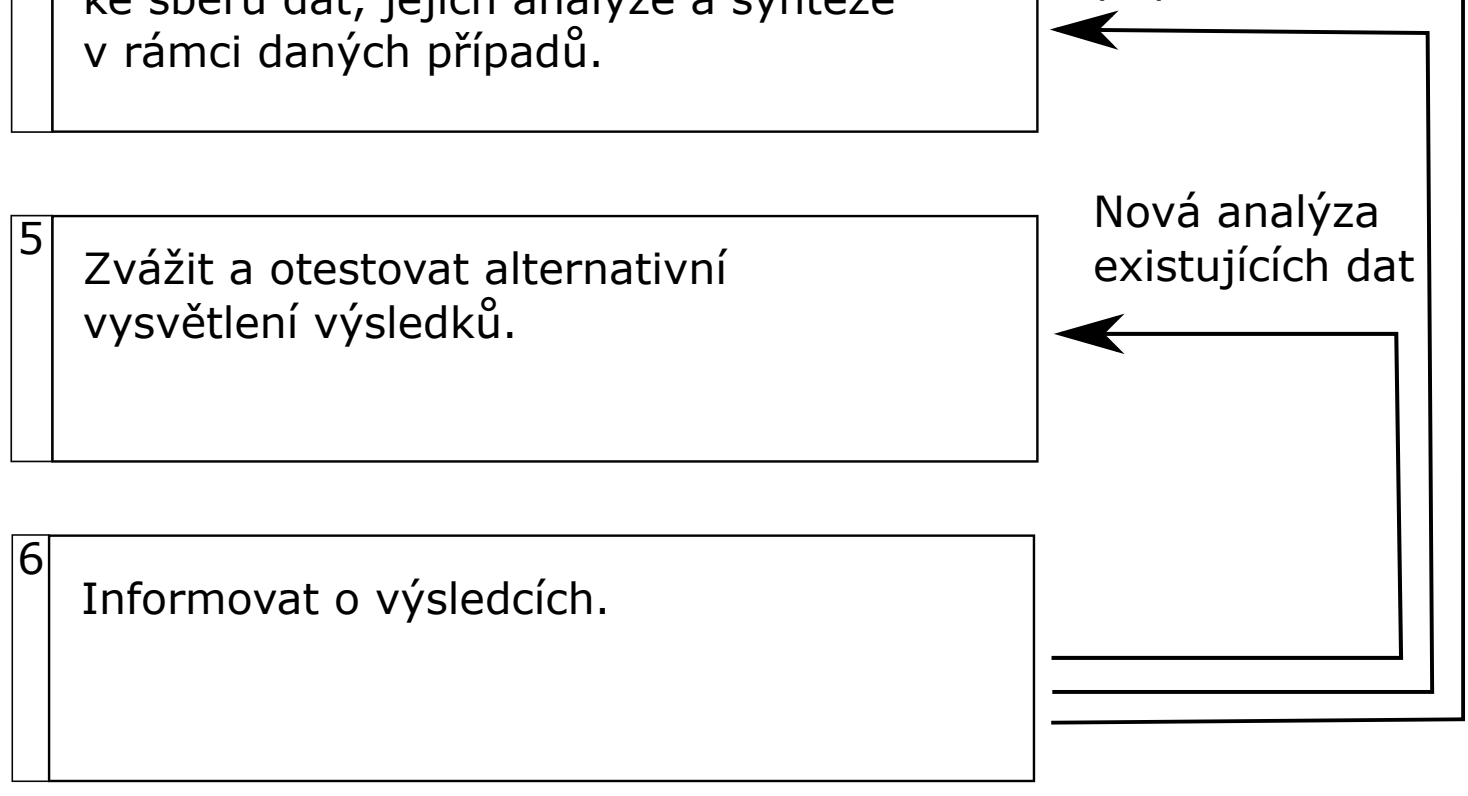

Obrázek 1. Postup srovnávací případové studie v šesti krocích (upraveno podle Goodrick, 2014). 
Pro srovnávací případovou studii je podobně jako pro realizaci běžných př́ipadových studií typická triangulace dat a výsledkủ. Slouží ke kontrole odpovědí na deskriptivní otázky týkající se způsobů, jakými věci fungují, např. potvrzení výsledků z rozhovorů př́mým pozorováním. Triangulace může být použita také jako kontrola síly odpovědí na kauzální otázky, např. indentifikací a vyloučením alternativních výsledků nebo identifikací a vysvětlením výjimek z hlavního pozorovaného jevu.

Důležitý je nepochybně výběr srovnávaných případů. Lor (2011, s. 11) uvádí, že nejlépe mohou být případy zvoleny na základě toho, že jsou pro zkoumaný jev reprezentativní, nebot' př́padové studie mají být prováděny s cílem tvořit hypotézy, vysvětlit daný fenomén, odhalit kauzální vztahy a poskytnout poznatky o mechanismech a cestách realizace daného jevu v heterogenních kontextech. Uvádí také, že výběr může být zdůvodněn tím, že případy ve zvolených zemích ještě studované nebyly, př́ípadně tím, že jsou ve vztahu k dalším př́ípadům nebo výzkumům důležité. Výzkumník může podle Lora (2011) argumentovat také pouze tím, že vybrané případy ve zvolených zemích zná a má k nim dobrý př́stup.

Srovnávací případová studie má nepochybně své limity. Arnove (2013, s. 15) například upozorňuje na nebezpečí, že výzkumník bude ukazovat světu pouze pohled, se kterým je seznámen, případně že se bude snažit zobecňovat výsledky z jednoho prrípadu na další př́ípady či jiné instance, které jsou ale danému př́ípadu nepřiměřené.

\subsection{Large-scale surveys}

$\mathrm{V}$ posledních desetiletích vzniklo velké množství tzv. large-scale surveys, tedy velkých studií o různých tématech $\mathrm{z}$ oblasti pedagogických jevů. Jsou zaměřeny jak na obecná témata, jako je dostupnost či kvalita vzdělávání, tak na specifičtější témata, jako jsou výsledky vzdělávacích procesủ. Zejména druhé z nich se staly zdrojem nepřeberného množství dat, jež poskytují možnost identifikovat pozici některé ze zúčastněných zemí v celkovém obraze, tedy ve srovnání se zeměmi jinými. Jedná se o studie, které jsou organizačně, personálně, časově a finančně velmi náročné. Nabízí se tedy možnost, že komparativisté budou pracovat s výsledky těchto velkých studií. Mohou v nich vyhledávat relevantní témata pro svoje interpretace, výsledky kriticky hodnotit a mohou je propojovat neotřelým způsobem tak, aby poskytly novou informaci. Mohou také vytvářet kvalifikované „sumáře“, v nichž komentují existující data a zasazují je do kontextu dané země. 
Může se zdát, že práce s large-scale surveys je ve srovnávací pedagogice relativní novinkou, alespoň viděno optikou české situace ${ }^{6}$, ale není tomu tak. Tradice sahá nejméně do poválečného období k iniciativám UNESCO, dále k IEA (International Association for the Evaluation of Educational Achievement), do přelomu 50. a 60. let se známými studiemi TIMSS, PIRLS, ICCS a k zapojení OECD v podobě studií PISA, IALS, SIALS, PIAAC nebo výroční zprávy Education at a Glance. Spadá sem také angažmá Evropské unie zejména prostřednictvím databáze EURYDICE ${ }^{7}$, jež je považována za hlavní zdroj současných reliabilních dat o evropském vzdělávání.

Nejen práce s daty z těchto velkých studií, ale především podíl na jejich iniciaci je spojen s celou řadou významných jmen srovnávacích pedagogů: Bereday (1964), Noah a Eckstein (1970), Husén a Postlethwaite (1989), Crossley a Broadfoot (1992), Rust a kol. (1999), Goldschmidt, Choi a Martinez (2004), Baker (2009), Davier a kol. (2013).

Je ovšem třeba brát v potaz také kritiku, která se na adresu využívání dat z velkých výzkumů a veřejných databází ozývá. Např́klad Bray (2007, s. 35-37) formulují limity takové srovnávací práce do tří bodů:

- velkou roli hraje kultura, statistika nám ji nevysvětlí a ani ji není schopna zahrnout;

- statistická data je vždy možné interpretovat různými způsoby;

- kvưli důrazu na statistická data mají státy tendenci je „naklánět” tak, aby ze srovnání vyšly dobře, což znamená, že prezentovaná statistická data nemusí nutně vypovídat o skutečné situaci dané země.

Skepsi zmíněných autorů vůči využívání dat z large-scale surveys by bylo možné podpořit i dalšími argumenty, jako např́íklad že práce s jejich daty ignoruje lidskou a kulturní dimenzi, že nevysvětlí anomálie a neumějí uvést důvody, proč jsou rozdíly ve statistických údajích mezi zeměmi, že nejsou schopny navodit více možností interpretace, že umožňují, aby si zúčastněné země vybíraly takové výsledky, které je zobrazují v lepším světle apod. To všechno má racionální základ, na druhé straně by ale bylo chybou nevidět jejich benefity. Podle Keatese (2012, in Marshall, 2014) je to především snadný

6 Česká republika, jak známo, se do těchto studií začala zapojovat až od druhé poloviny 90. let minulého století.

7 Tento přehled nemá být úplným výčtem, má jen naznačit nejvýznamnější organizace a instituce, jež se v tzv. large-scale surveys angažují, Světovou banku nevyjímaje. 
způsob, jak si mohou vzdělávací systémy na celém světě nastavit zrcadlo o vlastním pokroku a blíže se podívat na to, co se od sebe navzájem mohou naučit. A samozřejmě analýza dat ze sekundárního zdroje má řadu výhod pro výzkumníky, kteří se mohou dostat k vysoce kvalitním datům bez časových a finančních investic do jejich sběru. Záleží potom na nich, jak s daty pracují, jak bohatě je interpretují a jaké závěry z nich vyvozují. Jinými slovy, jak překračují limity, které plynou z podstaty typu dat, s nimiž pracují.

Inspirativním způsobem o využívání large-scale surveys ve srovnávacích studiích uvažují z pozic neo-institucionální teorie Wiseman a ChaseMayoral (2013), když poukazují na to, že tyto studie mají velký smysl zejména v okamžiku, kdy se daří propojovat makro-úroveň s mikro-úrovní, globální s lokálním, všechny úrovně kontextů pedagogických jevů a jejich vzájemného ovlivňování.

\section{Modely komparace}

Dostáváme se ke stěžejnímu momentu komparativních studií, tedy k samotnému srovnávání. Již jsme pojednaly o účelech srovnávacích výzkumů, o jejich základních paradigmatech a designech, které v sobě zahrnují i způsoby sběru dat a jejich analýzy, nyní věnujeme pozornost vlastnímu srovnávání, jež se někdy odbývá větou: „Byla použita srovnávací metoda.“ Ta však může mít různé podoby, proto zde uvádíme některé vybrané modely postupu srovnávání.

Prvním modelem je Beredayův (1964) klasický komparativní model (viz obr. 2), jenž sestává ze čtyř kroků: z popisu, interpretace, juxtapozice a samotné komparace. Tyto kroky detailně popsal Vlček (2015, s. 403) nebo Lor (2011) či Manzonová (2007, s. 99) a ilustruje jej následující schéma. 
I. POPIS zjištování dat

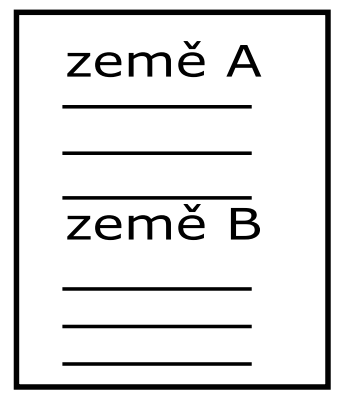

III. JUXTAPOZICE tvorba kostry

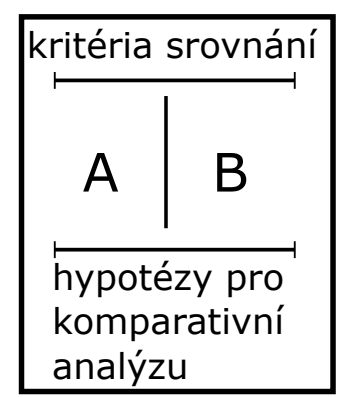

II. INTERPRETACE porozumění

\begin{tabular}{|l|l}
\hline $\begin{array}{l}\text { historický } \\
\text { politický } \\
\text { ekonomický } \\
\text { sociální }\end{array}$ & $\begin{array}{l}\text { kontext } \\
\text { země A }\end{array}$ \\
\cline { 1 - 2 } $\begin{array}{l}\text { historický } \\
\text { politický } \\
\text { ekonomický } \\
\text { sociální }\end{array}$ & kontext \\
\end{tabular}

IV. KOMPARACE vlastní srovnání

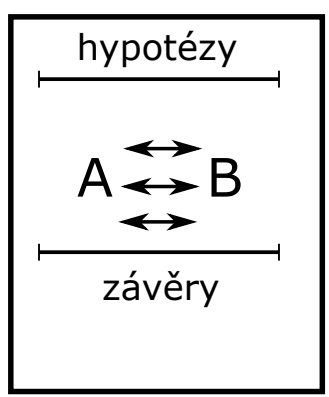

Obrázek 2. Beredayův model srovnávací analýzy ve čtyřech krocích (upraveno podle Bereday, 1964, in Manzon, 2007, s. 99).

Nejnověji aktualizoval tento postup Phillips (2006, s. 289-291; viz obr. 3) zdůrazněním role kontextu a historického pozadí sledovaného jevu. Jeho schéma začíná konceptualizací otázek, které budou řešeny v prvním kroku bez specifického kontextu. Smyslem je identifikovat výzkumné otázky a „neutralizovat" je od určitého kontextu. Typickou otázkou pro tento první krok je: „Jaká je povaha zkoumaného jevu?“ Druhým krokem je podle Phillipse detailní popis daného pedagogického jevu ve zkoumaných zemích již s plným důrazem na lokální kontext (historický, geografický, politický, náboženský, jazykový). Hlavní otázkou pro tuto fázi je: „Jaká je situace jevu v kontextu X a v kontextu Y?" Třetí fáze zahrnuje pokus skrze získaná data izolovat rozdíly pomocí přímého srovnání sledovaného jevu. Otázka zní: „Jak jiný/podobný je jev v kontextu X a jak je jiný/podobný v kontextu Y?“ Čtvrtá fáze 
je explanační, takže navrhuje vysvětlení za pomoci formulace hypotéz: „Co může způsobovat rozdílnosti/podobnosti $\mathrm{v}$ odpovědích na otázky $\mathrm{z}$ předchozí, třetí fáze?" V pátém a šestém kroku se znovu zvažují původní otázky a hledá se možnost aplikovat výsledky do jiných situací, v nichž mohou být zobecnitelné. Otázka uvozující tyto fáze zní: „Jestliže jsme našli rozdíly/podobnosti, jaké jsou implikace těchto rozdílností/podobností pro jiný kontext (Z)?" Původní otázky jsou nově konceptualizované s cílem určit, zda analýza přinesla takové výsledky, které je možno zobecnit. Schematicky ukazuje Phillipsův postup následující obrázek.

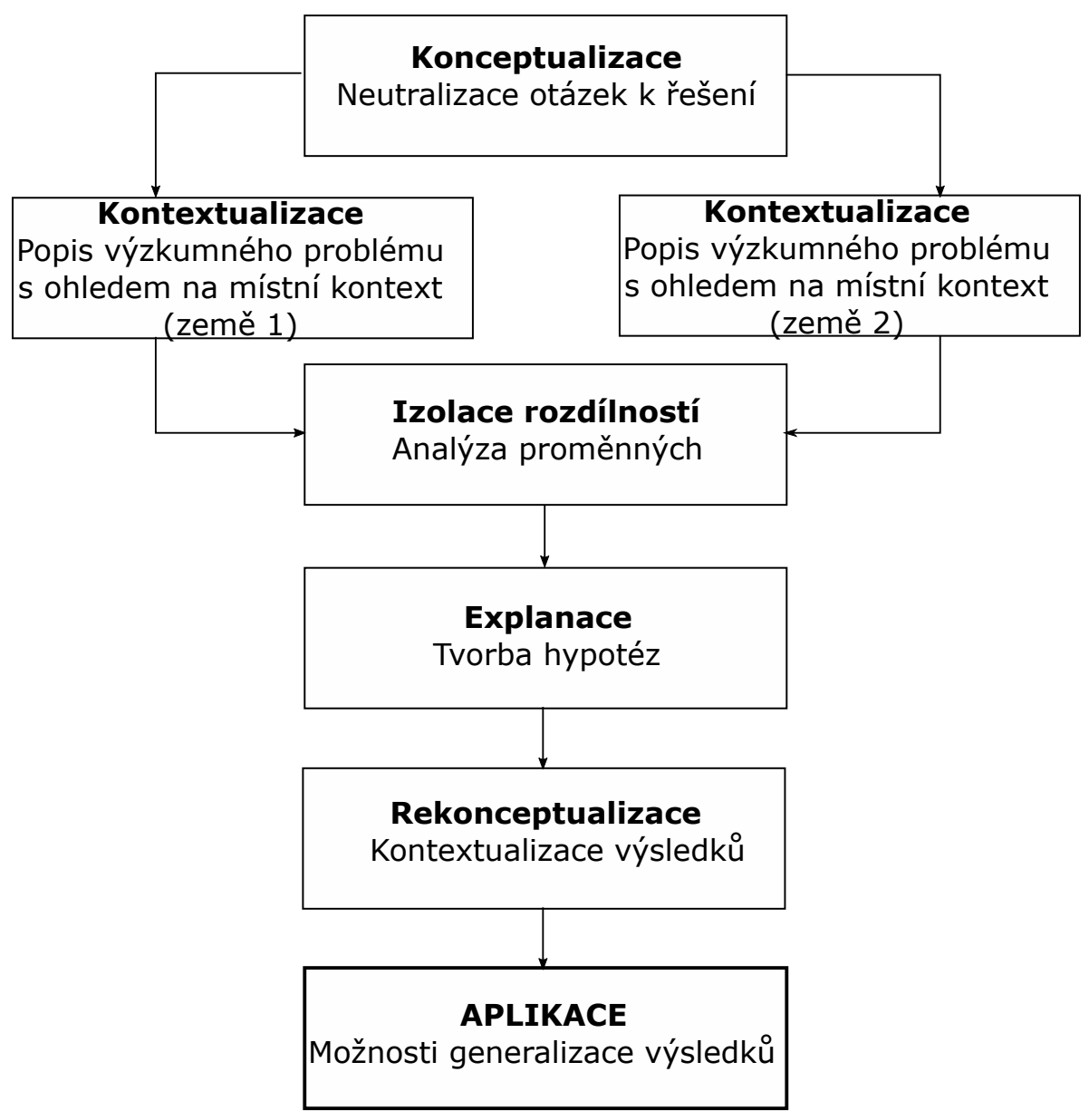

Obrázek 3. Phillipsův model srovnávací analýzy (upraveno podle Phillips, 2006).

Ve Phillipsově modelu je důležité zaznamenat důraz, který klade na kontext sledovaného jevu. Podle něj existuje mnoho způsobů, jak charakterizovat komparativní proces, klíčovým momentem ale je, že fenomény a otázky, 
které jsou v centru zájmu, musí být zaznamenány nejprve v jejich vlastním kontextu a teprve tyto kontextualizované fenomény mohou být podrobeny systematické srovnávací analýze s cílem identifikovat podobnosti a rozdílnosti, jež umožní vysvětlení daného jevu.

Dalším modelem srovnávacího postupu je model Lorův (Lor, 2011), který staví na tom, že je důležité jasně definovat hranici mezi odlišností, podobností a stejností. Teoretický koncept, který je zkoumán ve více než jednom kontextu, musí být měřen nebo pozorován pomocí indikátorů nebo operacionalizovaných konceptů, které nejsou identické, ale ekvivalentní (rovnocenné). Co je myšleno ekvivalencí oproti identičnosti? Lor uvádí čtyři oblasti, ve kterých lze hledat ekvivalenci: (1) kulturní ekvivalence (fenomény jsou v různých kulturách vnímány stejným způsobem); (2) kontextuální ekvivalence (jevy nebo aktéři mají stejnou relativní pozici ve struktuře systémůำ); (3) strukturální ekvivalence (jevy jsou agregovány do vyšších celků, jež jsou klasifikovány jako ekvivalentní ); (4) funkcionální ekvivalence (různé jevy či aktéři hrají stejnou roli ve zkoumaných systémech ${ }^{10}$ ). Lorův postup naznačuje schéma v obrázku 4.

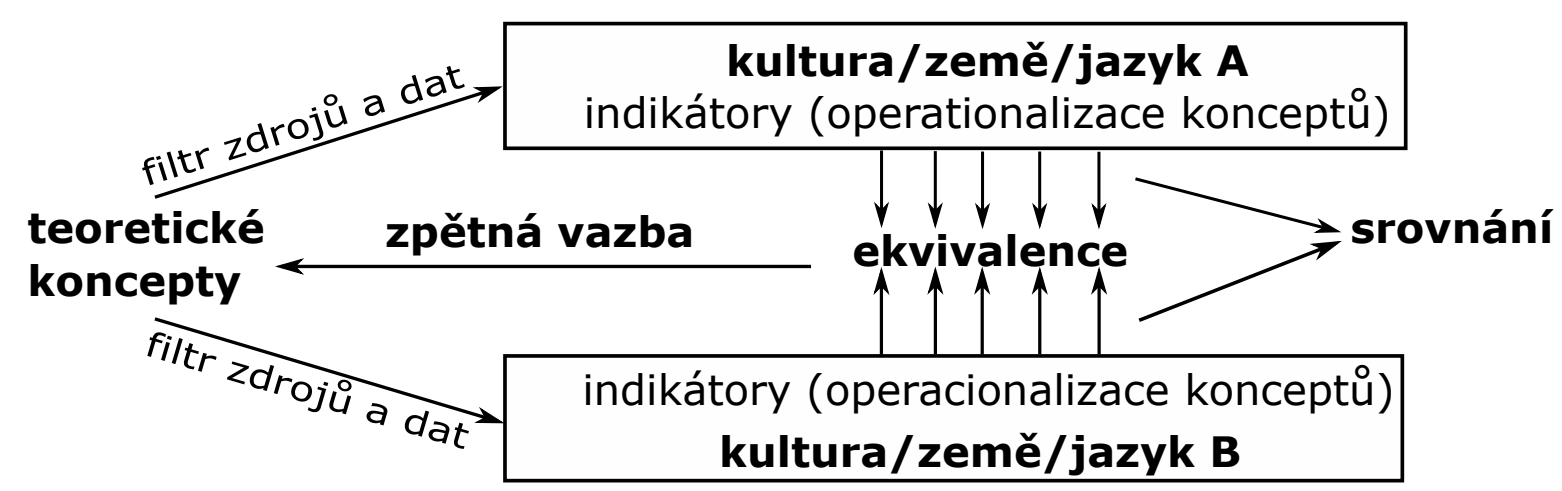

Obrázek 4. Lorův model srovnávací analýzy (upraveno podle Lor, 2011).

\footnotetext{
Např ředitelé škol mají v různých kontextech různá označení, ale jejich pozice je stejná.

Např. francouzské lycées a nizozemské gymnasium, nikoli německá Hochschule.

10 Např. US Library of Congress je zároveň ekvivalentem národní knihovny v jiných státech a může tak být zařazena do mezinárodního výzkumu národních knihoven.
} 
Za povšimnutí v tomto schématu stojí moment zpětné vazby, který ukazuje, že teoretický koncept, jenž slouží jako výchozí bod studie, může být v průběhu procesu zpracovávání rovnocenných (ekvivalentních) operacionalizovaných konceptů a indikátorů upravován.

Poslední model srovnávání, který zde uvádíme, už nemá povahu obecných modelů srovnávací analýzy, ale je to velmi dobrá ukázka toho, jak lze koncipovat srovnávací studii. Nemusí se totiž nutně jednat o přesné použití nějakého již existujícího modelu srovnávání, spíše jde o to, ujasnit si vlastní postup $\mathrm{v}$ jeho jednotlivých fázích, sladit téma a obsah s metodologií sběru dat, jejich analýzy a úrovně interpretace. Z množství existujících příkladů vybíráme případovou srovnávací studii ${ }^{11}$ McNessové (2004). Autorka postupovala od popisu nejobecnějšího kontextu až po popis konkrétních případů. Začíná deskripcí globálního a evropského kontextu, pokračuje kontextem sociokulturním a historickým, a to již na př́kladech školských systémů v Anglii a Dánsku. Přes analýzu vzdělávací politiky v obou zemích a provedený předvýzkum se dostává ke konkrétním případovým studiím v obou zkoumaných zemích. Model McNessové vychází z Beredayova čtyřkrokového modelu srovnání a doplňuje jej o globální a evropský kontext, se kterým Bereday ve své době nepracoval (viz obr. 5).

\section{Lokalizace sběru dat, počet případů a jednotka analýzy}

Volbou modelu srovnávání ovšem rozhodování výzkumníka stále ještě nekončí. Je třeba dále přemýšlet o volbě míst, kde bude svoji srovnávací studii provádět, také o tom, do jaké hloubky při srovnávání půjde, což je spojeno s rozvahou o počtu př́padů, a konečně o tom, jak a z jakých úrovní systému bude volit svoji jednotku analýzy. Těmto tématům se věnujeme v další části tohoto článku.

11 Př́iklad je vybrán ze tří případových studií uvedených v tabulce 2 (Culture, Context and the Quality of Education: Evidence from a Small-Scale Extended Case Study in England and Denmark). 


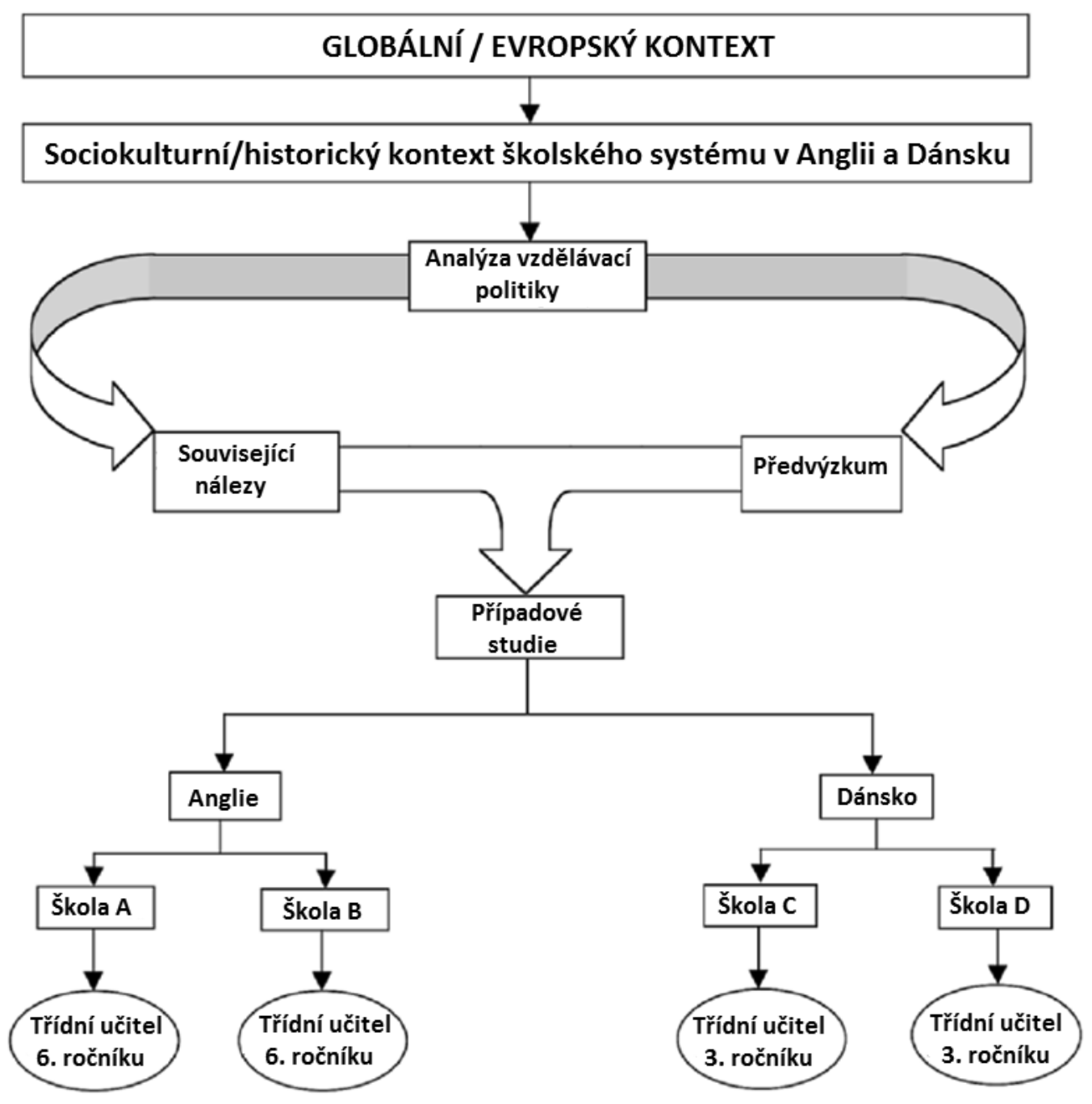

Obrázek 5. Kultura, kontext a kvalita vzdělávání: zjištění z případových studií v Anglii a Dánsku (McNess, 2004).

\subsection{Lokalizace: blízkost versus vzdálenost}

Vycházíme z podstaty srovnávacích studií, tedy ze zkoumání dvou a více vzdělávacích jevů v různých systémech s cílem zjistit, jak si jsou podobné a v čem jsou odlišné (Theisen \& Adams, 1990). Zásadní otázka ve výzkumu několika zemí (lokalit, regionư ${ }^{12}$ ) tedy je, které země, lokality či regiony k výzkumu

12 Uvědomujeme si, že u označení místa srovnávání může vyvstat terminologická otázka, jež se ptá po adekvátnosti použití termínu země, region, stát apod. Domníváme se, že to je součástí rozvahy nad samotným výběrem místa pro srovnávání zvoleného jevu, nikoli předmětem této studie. 
zvolit. Nemá smysl srovnávat subjekty, které jsou natolik odlišné, že může být jen těžko nalezeno něco společného. Nemá ani smysl srovnávat entity, které jsou si tak podobné, že lze mezi nimi jen stěží najít nějakou odlišnost ${ }^{13}$. Platí tedy zásada, že pro srovnání volíme země, jež jsou srovnatelné s ohledem na zkoumaný fenomén nebo teorii, která je východiskem pro danou studii.

Prvním krokem je podle Lora (2011, s. 14) zúžení zkoumání vzhledem $\mathrm{k}$ zemím $\mathrm{v}$ určité oblasti nebo určité kategorii (např. demokratické státy, frankofonní státy, islámské státy, rozvojové země apod.). Dle Phillipse a Schweisfurthové (2008) potom následuje krok definující to, co mají zkoumané systémy shodné, a následně se má výzkumník věnovat odlišnostem, které zjistí a vysvětlí. Jedná se o ekvivalenci ve stejných čtyřech úrovních, jak je ve svém modelu pro komparaci popisuje Lor (2011): kulturní, kontextuální, strukturální a funkcionální. Po jasném definování těchto čtyř úrovní se přechází $\mathrm{k}$ vysvětlování nalezených rozdílností a podobností, což je stěžejním kritériem pro výběr případů a lokalizaci srovnávacích jednotek. Země ke srovnání si výzkumník může poté volit podle podobnosti, nebo naopak podle odlišnosti.

Zvolí-li výzkumník práci s nejvíce podobnými systémy, doporučuje se uvést do schématu, v čem jsou země stejné či podobné, přičemž kritéria pro posuzování nejsou fixní, nýbrž výzkumník je volí podle vztahu ke zkoumanému jevu. Jako příklad uvádíme obrázek 6 ze srovnávacího výzkumu veřejných knihoven (Lor, 2011, s. 15).
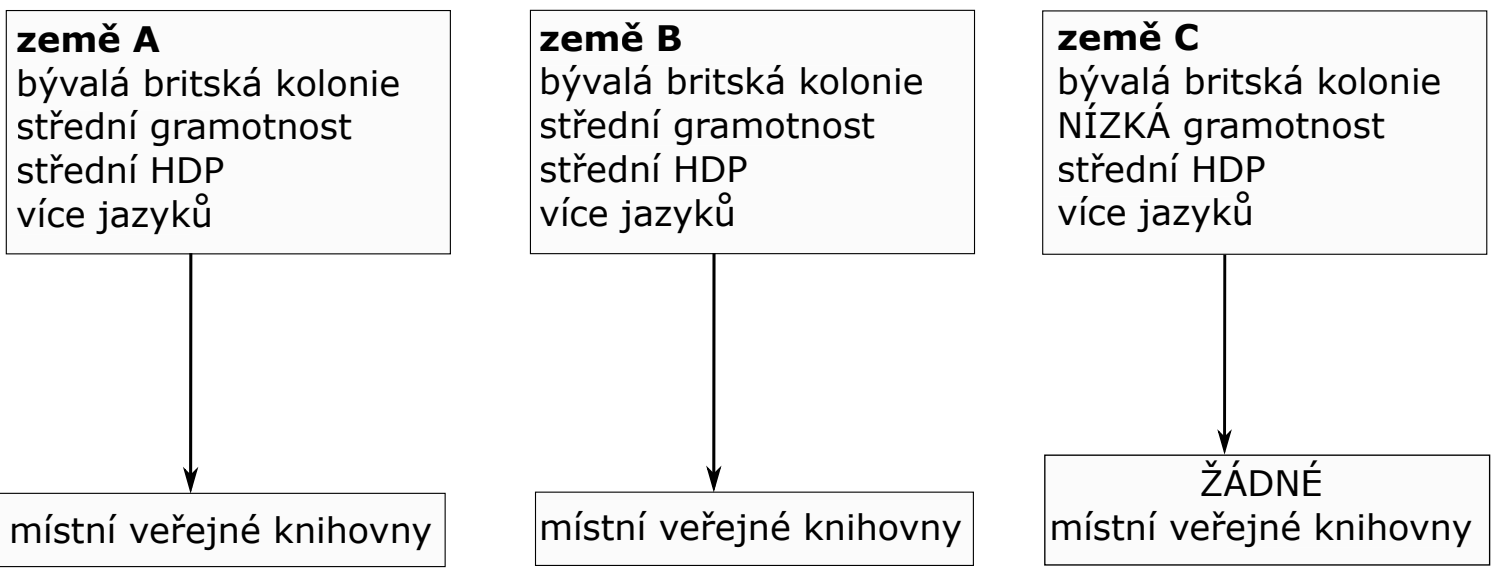

Obrázek 6. DNPS: Design nejvíce podobných systémů (upraveno podle Lor, 2011).

13 Zde ponecháváme stranou diskuse o izomorfnosti pedagogických jevů vyplývající z globálních vlivů na vzdělávání v různých úrovních a v různých vzdělávacích systémech. 


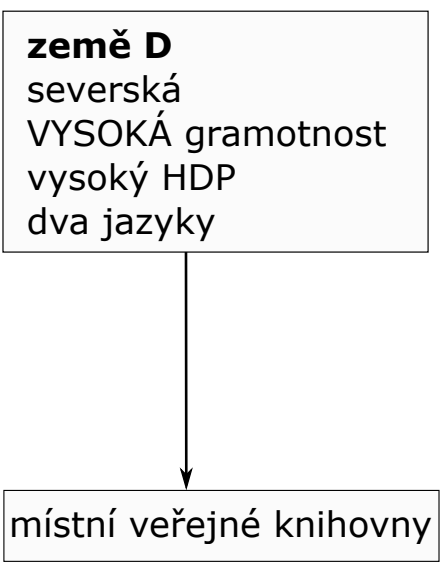

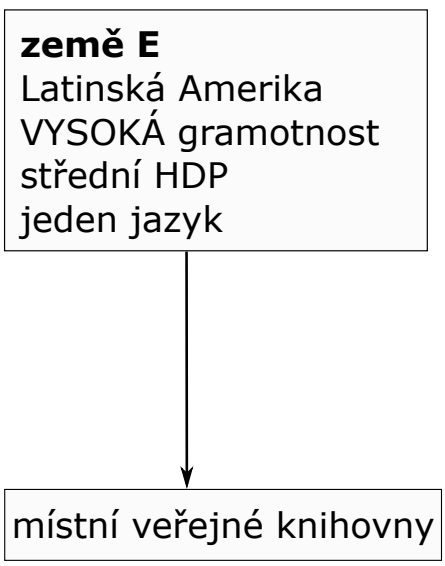

země $\mathbf{F}$ bývalá britská kolonie VYSOKÁ gramotnost středně nízký HDP více jazyků

Obrázek 7. DNOS: Design nejvíce odlišných systémů (upraveno podle Lor, 2011).

Pokud výzkumník zvolí naopak srovnávání mezi velmi různými systémy, také by měl do schématu zaznamenat, v čem se systémy liší. Nemá-li komparace ztratit smysl, je třeba i přes různé kontexty najít a zaznamenat alespoň něco, co mají zkoumané systémy společného (viz obr. 7).

Oba uvedené postupy při výběru lokalizace srovnávací studie shrnuje Hefler (2013) jako design nejvíce podobných systémů (DNPS) versus design nejvíce odlišných systémů (DNOS). Autor upozorňuje na důležitost vysvětlení i minimálních rozdílů (v případě DNPS) nebo izolovaných rozdílů (v případě DNOS) v jednotlivých vstupních proměnných, nebot' ty mohou následně vysvětlit rozdíly ve výsledcích.

Důležitost popisu podobnosti a různosti ve srovnávacích studiích zdůrazňují také Marginson a Mollisová (2001, s. 585). Některé vzdělávací systémy mohou $\mathrm{v}$ jednom hledisku představovat rozdílnost, ale $\mathrm{v}$ jiném naopak stejnost či podobnost. Srovnávací pedagogika by se navíc měla věnovat jak dominantní kultuře, tak alternativním hlasům a měla by umožnit pohybovat se mezi globálním, národním a místním, mezi různými teoretickými východisky a např́č různými obory.

V úvahu je třeba brát také fakt, že země jako zvolená lokalita pro komparaci nemusí být vždy dobrou volbou, nebot', jak upozorňuje Phillips (2006, s. 313), části zemí mohou mít nastavena různá pravidla a politiky. Jak známo, typickým př́kladem jsou v tomto ohledu angloamerické vzdělávací systémy (USA, Kanada, Velká Británie). 
Velmi zajímavá a $\mathrm{z}$ hlediska metodologie srovnávacích studií závažná je myšlenka Marginsona a Mollisové (2001, s. 585) o tom, že design výzkumu do jisté míry předznamenává, zda bude výzkumník při komparaci nalézat spíše shody nebo spíše rozdíly. Podle nich kvalitativní studie projektují více růzností, zatímco kvantitativní studie projektují více shod. Když postupujeme kvalitativně, tedy čím detailněji na jev nahlížíme, čím komplexnější kritéria používáme v pozorování daného jevu, tím více se stejnost/podobnost mění $\mathrm{v}$ rozdílnost. U kvantitativních studií se zase rozdílnost může změnit v podobnost fenoménu, když např. v large-scale surveys o vzdělávacích výsledcích jsou uvedena stejná numerická data, jež však mají jiný kontextuální význam. V mezinárodních srovnáních se však tato rozdílnost může vytrácet.

\subsection{Počet případů: hloubka versus šírka}

Při volbě počtu případů hraje roli, do jaké hloubky či šířky tématu výzkumník mírí. Počet zvolených jednotek pro analýzu souvisí přirozeně s celým metodologickým postupem pro danou studii, tedy včetně účelu studie a jejího designu. Zjednodušeně řečeno, čím více zemí/systémů zkoumáme, tím povrchnější informace budeme pravděpodobně sdělovat. Naopak, srovnávámeli pouze dvě země / dva systémy, můžeme být - a měli bychom být - velmi detailní (Lor, 2001). Tuto tezi ilustruje následující graf (obr. 8).

Lorovu zřejmou tezi doplňuje Theisen a Adams (1990, s. 280), když říká, že bohatost $\mathrm{v}$ oblasti popisu a analýzy je zpravidla poskytována na úkor omezeného množství případů, které jsou studovány. Pozorování mohou být platná v konkrétním kontextu, v němž byla studie prováděna, ale poskytují jen skromné důkazy umožňující zobecnění. Jiní výzkumníci, kteří zpracovávají velké množství případů, naopak obětují „hustý popis“, aby se mohli věnovat zobecnění. 


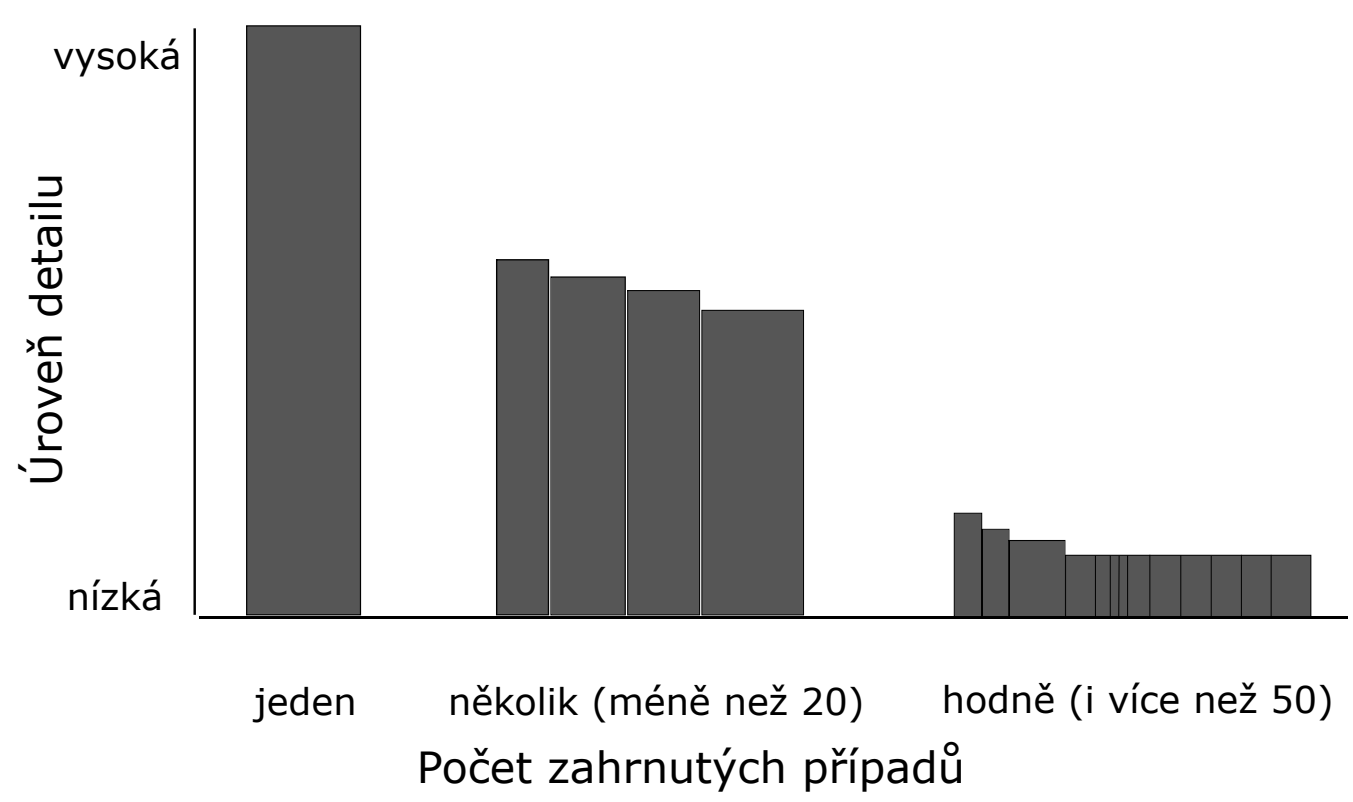

Obrázek 8. Počet zahrnutých států (upraveno podle Lor, 2011).

\subsection{Jednotka analýzy: volba tématu}

Volba jednotky analýzy je pro dosažení účelu studie a jejího cíle stěžejní (Bray \& Thomas, 1995; Phillips \& Schweisfurth, 2008). Vlček (2015, s. 403), Manzonová (2007, s. 88) či Thomas (1990, s. 9) uvádějí, že definice objektu zkoumání a určení cíle výzkumu jsou základními stavebními kameny komparativního výzkumu, na které navazují další kroky.

Tradičně se výzkumy srovnávací pedagogiky jako na jednotku komparace zaměřovaly na geografické subjekty. Srovnávání se ale může zaměřovat také na jiné subjekty, jako je kultura, politika, kurikulum apod. Jako nejběžnější př́klady jednotek analýzy uvádí Manzonová (2007, s. 97) např. srovnávání míst, systémů, kultur, hodnot, vzdělávacích výsledků, vzdělávacích politik, srovnávání kurikul, vzdělávacích organizací, způsobů učení a pedagogických inovací. Komparace je však vždy spojena s nějakými geografickými místy/ subjekty. Proto je definování geografické hranice srovnání pro jakoukoli srovnávací studii podstatné (Manzon, 2007).

Nápomocná při stanovování jednotky analýzy může být tzv. Brayova a Thomasova krychle (1995; viz obr. 9), jež klasifikuje srovnávací studie podle tří dimenzí srovnávání. 


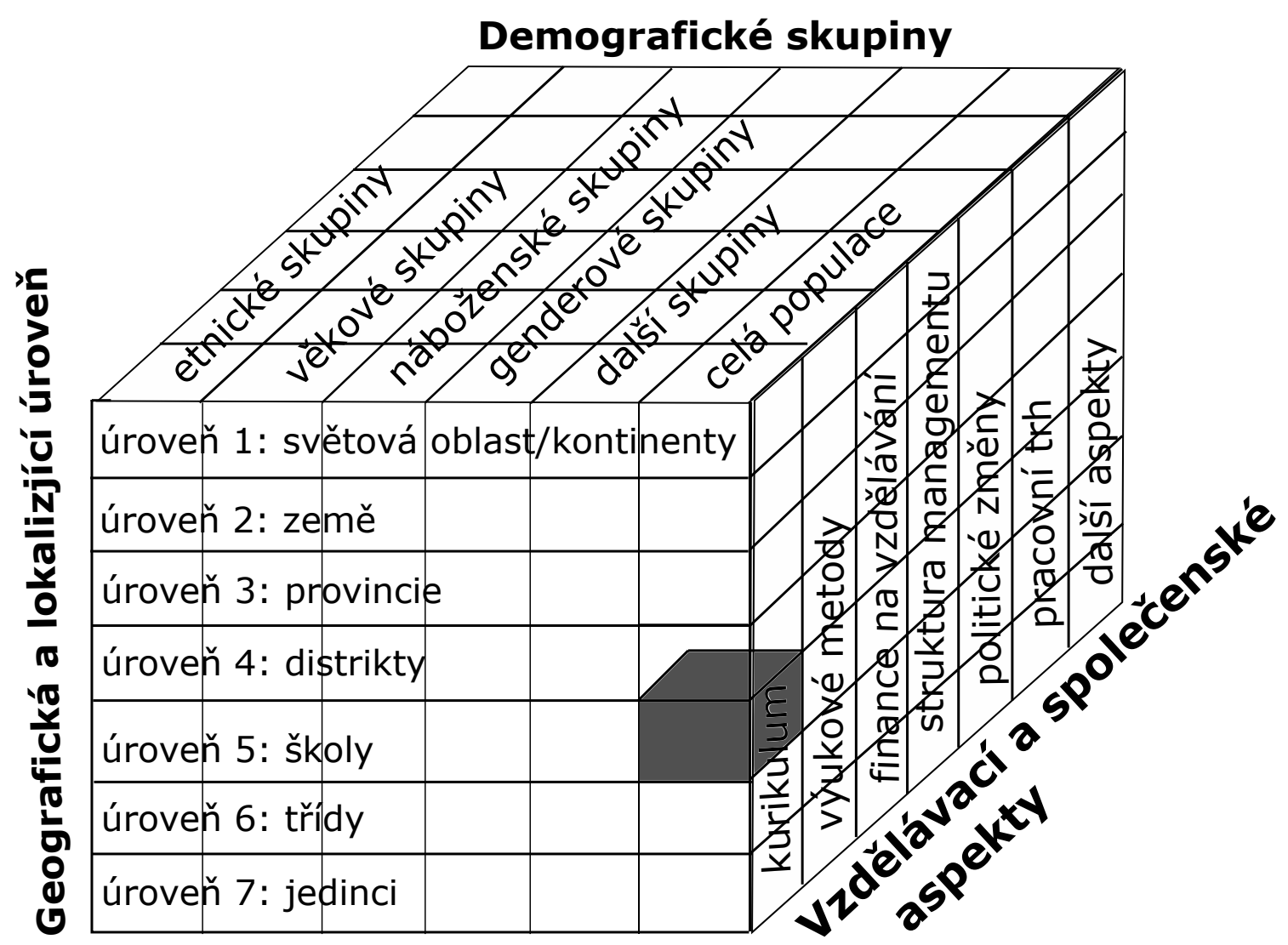

Obrázek 9. Brayova a Thomasova krychle (upraveno podle Bray \& Thomas, 1995).

Pozn.: Zvýrazněná „krychlička“ v obrázku reprezentuje komparativní studii kurikula pro celou populaci ve dvou či více školách.

Pointa této krychle má být podle Braye a Thomase ve výzvě k víceúrovňové analýze výchovných a vzdělávacích procesů, díky níž autoři dosáhnou mnohostranné a holistické analýzy daných fenoménů. Bray a Thomas si totiž všimli, že hodně autorů se drží pouze jedné úrovně. Vyzývají tedy autory, aby alespoň zmapovali, do které úrovně jejich jednotka analýzy spadá, jaký vliv mají ostatní úrovně na jejich zkoumaný fenomén a kde jsou limity takového př́stupu. Krychle Braye a Thomase je velmi citovaná jak v literatuře explicitně spojené se srovnávací pedagogikou (Ginsburg, 1995; Broadfoot, 1999; Arnove, 2013), tak i v širší literatuře (Winzer \& Mazurek, 2012; Ballantine, 2001). Obecně je tato krychle považována za prospěšnou pomůcku a řada autorů si ji upravuje ke svému vlastnímu použití. 


\section{$7 \quad$ Role výzkumníka}

Výzkumníkova role ve srovnávací studii se liší od role výzkumníka jiných výzkumů v několika ohledech. Záleží na tom, jaký účel jeho studie má a jakou pozici pro př́stup ke srovnávání si komparativista zvolí. Chce být glosátorem? Chce být cizincem? Chce být účastníkem?

Autoři odkazují především na dvě výzvy, se kterými se výzkumník musí potýkat: problém etnocentrismu a problém jazykový.

Na problém etnocentrismu upozorňují Phillips a Schweisfurthová (2008, s. 93) a vyzývají komparativisty, aby si byli tohoto problému vědomi a pracovali s ním. Konkrétně připomínají, že ,je důležité uvědomovat si, že přicházíme jako výzkumníci s řadou předsudků založených na dlouhé životní zkušenosti nahlížení na problémy ve vzdělávání. Výzkumník se musí snažit vytvořit jakousi neutralitu, aby porozuměl správně ostatním vzdělávacím systémům a prvkům, které ho právě zajímají". K tomu Theisen a Adams dodávají (1990, s. 279), že člověk je zkrátka omezen kulturou, ve které vyrostl, a při tvorbě srovnávací studie si musí být tohoto omezení vědom.

King (1967) ve své době vyzýval komparativisty k návštěvě země, na níž provádějí výzkum: „Efektivní srovnání je při použití syntetizujících závěrů z dostatečných důkazů a indikací. Jaká je lepší cesta dospět k takovému srovnání, než návštěvou země nebo oblasti s dobře informovanými postřehy (s dobrou teoretickou průpravou) a pokud možno s dobrým průvodcem a dobrým př́itelem, kteří nás v dané zemi přijmou?“ (King, 1967, s. 348).

Druhým problémem je jazyk. Bereday (1964, in Phillips, 2006, s. 312) tvrdil, že výzkumník musí být kompetentní v jazyku společnosti, ve které provádí výzkum. Phillips a Schweisfurthová (2008) jsou poněkud mírnější, když říkají, že znalost jazyka země, kde výzkumník provádí výzkum, je velkou výhodou, ale často je to podmínka nereálná. Marshallová (2014) na toto téma dodává, že právě neznalost jazyka země, v níž se provádí výzkum, vede výzkumníky k častému používání sekundárních dat: politických dokumentů, kurikul či vzdělávacích statistik. Klíčovou roli pro komparativisty tak hraje internet a statistické údaje. 
Za hlavní jazyk srovnávací pedagogiky je již řadu let považována angličtina. ${ }^{14}$ Napovídá tomu množství anglicky publikovaných článků a odborné literatury, stejně tak jako explicitní upozorňování řady srovnávacích pedagogů (např. Preston, 2001, s. 80; Khakpour, 2012, s. 25), že angličtina je pro srovnávací pedagogiku jazykem hlavním. To je fakt, který se ale současně stává také předmětem určitých sporů. Mason (2007, s. 239), Lee s Manzonovou (2007, s. 263), Leung s Parkovou (2007, s. 394) a Phillips se Schweisfurthovou (2008) upozorňují v tomto kontextu na problematiku překladů, nebot' různé jazyky používají různé pojmy týkající se téhož jevu a může být proto obtížné některé pojmy překládat do/ze svého mateřského jazyka. ${ }^{15}$

\section{Závěr}

Impulsem pro vznik tohoto článku byla osobní zkušenost: druhá z autorek se snažila koncipovat svůj disertační komparativní projekt, od první z autorek se očekávalo, že jí v tom bude nápomocná. Při snaze nalézt pro projekt metodologickou inspiraci jsme narazily na řadu textů domácí provenience (Průcha, 2006, 2015; Walterová, 2015) především kritizujících nedostatečné metodologické, ale také teoretické, tematické a institucionální ukotvení tohoto oboru u nás. Proto jsme se rozhodly na základě sesbíraných materiálů, primárně zahraničních, zpracovat přehled toho, jak lze o koncipování srovnávací studie uvažovat, čím se nechat inspirovat.

Vyšly jsme z Průchovy (2006, s. 21) definice, který disciplínou srovnávací (komparativní) pedagogika označuje jednak teorie, jednak výzkumné aktivity, které se zabývají zkoumáním charakteristik a fungováním vzdělávacích systémů různých zemí, jejich popisem, srovnáváním a hodnocením.

Právě k výzkumným aktivitám spadajícím do tohoto oboru jsme se pokusily vytvořit alespoň základní přehled možností, jak koncipovat metodologický postup ve srovnávacích studiích. Nečiníme si nárok na úplnost, nebot’ vyčerpávající přehled ani není možný. Stejně jako není možné pokrýt všechna témata, která se v diskusích o srovnávací pedagogice objevují. Nepochybně

14 Arnove (2013, s. 12) ale připomíná, že „,ačkoli si mnozí výzkumníci uvědomují, že angličtina bude s největší pravděpodobností v dohledné době jejich primárním jazykem při diseminaci výzkumů a informačních výměnách, je třeba mít na paměti nedávný pozoruhodný nárůst v používání čínštiny v oboru“.

15 Takových př́kladů bychom $\mathrm{v}$ oblasti pedagogické terminologie našli mnoho. Typicky např education s českým významem vzdělání i výchova. 
jsme tedy ponechaly stranou celou řadu dalších podstatných otázek srovnávací pedagogiky současnosti, jako je např. téma multidisciplinarity, na němž se shodují autoři jako na stěžejním pro dobrou srovnávací studii, či téma globalizace, s nímž pracuje mimo jiné teorie neoinstitucionalismu. Pozorný čtenář si jistě povšimne také toho, že jen okrajově jsme v úvodu zmínily nejrůznější teorie, které mohou být východiskem srovnávacích studií, respektive mohou sloužit jako interpretační rámec pro prezentaci získaných výsledků. Ty jsme ponechaly jako otevřené téma pro případné další kritické zpracování, jež by pro českého čtenáře bylo jistě užitečné.

V duchu kritického přehledu, který jsme si zvolily jako formát pro tento článek, se sluší provést kritickou bilanci dosavadního stavu, tedy dostupných metodologických postupů a jejich komponent ve srovnávací pedagogice. Máme-li tedy shrnout základní myšlenky tohoto textu, pak jsou to tyto: Podstatný je účel (cíl) srovnávacího výzkumu. Od něj se odvíjí volba metodologického paradigmatu a následného výzkumného designu. Volba výzkumného designu předznamenává všechny následující dílčí kroky, tedy výběr srovnávaných jevů, výběr lokalit, v jejichž kontextu jev existuje, techniky sběru dat, metody jejich analýzy, model srovnávání, volba hloubky analýzy podle počtu zkoumaných případů. Nemůžeme totiž, jak varoval již Sadler (1900, in Crossley, 1999, s. 250) „bloudit dle libosti mezi vzdělávacími systémy světa jako dítě potulující se po zahradě a sbírat květy z jednoho keře a některé listy z jiného a očekávat, že pokud se budeme držet toho, co jsme získali, a doma to dáme do zeminy, budeme mít živou rostlinu“.

Z přehledu metodologických postupů dále vyplývá, že komparativní studie, i když se primárně soustředí na synchronní zkoumání daného jevu, by neměly být ahistorické. Měly by vždy důsledně pracovat s různými kulturními, sociálními, politickými a ekonomickými kontexty zkoumaných pedagogických jevů a měly by ústit $\mathrm{v}$ uvážlivé interpretace a závěry. Takže multidisciplinarita, diachronní a kontextuální zakotvení by měly být základními znaky současných komparativních studií.

Kromě již v úvodu zmíněné teze, že neexistuje jeden metodologický postup pro komparace ve vzdělávání, že naopak v jejich různosti je potenciál, který je třeba rozvíjet, můžeme přidat další, a tou je, že není třeba vždy vytvářet zcela nové metodologické postupy. Ve srovnávací pedagogice totiž existuje, jak jsme se pokusily ukázat, poměrně pevný metodologický základ. Ten je ale potřeba znát a tvořivě s ním v každé komparativní studii pracovat. 
Změny ve vzdělávání v současném světě jsou natolik významné, v některých případech globální, v některých naopak zcela specifické, že stojí za to, abychom se je snažili opakovaně popisovat, rozumět jim, vysvětlovat je a hodnotit. To nám může pomoci při hledání inspirace v pozitivních prvcích a vyvarování se slepých uliček. Právě kvalitní a metodologicky validní srovnávací výzkumy jsou při této snaze velmi užitečným nástrojem. Zcela se ztotožňujeme s konstatováním Walterové ${ }^{16}$ (2015), že „přispět k interpretaci globálních fenoménů a porozumění vzdělávání v kontextu politických, sociálních, ekonomických a kulturních procesů by mělo být ctižádostí české srovnávací pedagogiky stejně tak, jako účast na utváření světové komunity srovnávacích pedagogư“. Necht' je tento článek chápán jako drobný krůček tímto směrem.

\section{Literatura}

Aikman, S. (2001). Literacies, languages and developments in Peruvian Amazonia. In B. V. Street (Ed.), Literacy and development: Ethnographic perspectives (s. 103-120). London: Routledge.

Alexander, R. J. (2000). Culture and pedagogy: International comparisons in primary education. Oxford: Blackwell.

Arnove, R. F. (2013). Introduction: Reframing comparative education. In R. F. Arnove, C. A. Torres, \& S. Franz (Eds.), Comparative education: The dialectic of the global and the local (s. 1-25). Boulder: Rowman \& Littlefield.

Baker, D. P. (2009). The invisible hand of world education culture. In G. Sykes, B. Schneider, \& D. N. Plank (Eds.), Handbook of education policy research (s. 958-968). New York: Routledge.

Ballantine, J. H. (2001). The sociology of education: A systematic analysis. Upper Saddle River: Prentice Hall.

Battle, J., \& Blowers, T. (1982). A longitudinal study of the self-esteem of students in regular and special education classes. Journal of Disabilities, 15, 100-102.

Bereday, G. Z. F. (1964). Comparative method in education. New York: Holt.

Bray, M., \& Thomas, M. (1995). Methodology and focus in comparative education. Dostupné z http://147.8.214.206/f/acadstaff/376/Bray_Methodology_\%26_Focus.pdf.

Bray, M., Adamson, B., \& Mason, M. (2007). Comparative education research. Approaches and methods. Hong Kong: Springer.

Broadfoot, P. (1999). Comparative research on pupil achievement. Learning from Comparing: New Directions in Comparative Educational Research, 1, 237-259.

Chabbott, C., \& Elliot, E. (Eds.). (2001). National research council. Understanding others, educating ourselves (Getting more from international comparative studies in education). Dostupné z http://www.nap.edu/read/10622/chapter/1\#iii

Crossley, M. (1999). Reconceptualising comparative and international education. Compare: A Journal of Comparative and International Education, 29(3), 249-267.

16 Profesorce Elišce Walterové děkujeme za inspirativní diskuse a kolegiální nasměrování k podstatným metodologickým zdrojům srovnávací pedagogiky. 
Crossley, M., \& Broadfoot, P. (1992). Comparative and international research in education: Scope, problems and potential. British Educational Research Journal, 18(2), 99-112.

Dash, K. K. (2005). Online research methods resource: Module - selection of the research paradigm and methodology. Dostupné $\mathrm{z}$ http://celt.mmu.ac.uk/researchmethods/Modules/ Selection_of_methodology/index. php

Davier von M., Gonzalez, E., Kirsch, I., \& Yamamoto, K. (Eds.). (2013). The role of international large-scale assessments: Perspectives from technology, economy, and educational research. Dordrecht: Springer.

Entwistle, N. J., \& Ramsden, P. (1983). Understanding student learning. London: Croom Helm.

Ginsburg, M. B. (1995). The politics of educators' work and lives. New York: Garland.

Goodrick, D. (2014). Comparative case studies, methodological briefs: Impact evaluation. Dostupné z https://www.unicef-irc.org/publications/pdf/brief_9_comparativecasestudies_eng.pdf

Goldschmidt, P., Choi, K., \& Martinez, F. (2004). Using hierarchical growth models to monitor school performance over time: Comparing NCE to scale score results. CES Report 618. Los Angeles: Center for the Study of Evaluation, University of California.

Hefler, G. (2013). Taking steps. Formal adult education in private and organisational life: A comparative view. Münster: LIT Verlag.

Hofstede, G. (2001). Culture's consequences: Comparing values, behaviors, institutions and organizations across nations. Thousand Oaks: Sage.

Hoskins, B. L., Barber, C., Van, N. D., \& Villalba, E. (2011). Comparing civic competence among European youth: Composite and domain-specific indicators using IEA civic education study data. Comparative Education Review, 55(1), 82-110.

Husén, T., \& Postlethwaite, T. N. (Eds.). (1989). The international encyclopedia of education. Supplementary volume one. Oxford: Pergamon Press.

Jayson, W. R., (2010). Challenges of adopting the use of technology in less developed countries: The case of Cambodia. Comparative Education Review, 55(1), 8-29.

Kandel, I. L. (1936). Comparative education. Review of Educational Research, 6(4), 400-416.

Khakpour, A. (2012). Methodology of comparative studies in education. Contemporary Educational Research Journal, 1, 20-26.

King, E. J. (1967). Other schools and ours. A comparative study for today. New York: Holt, Rinehart and Winston.

Lee, W. O. \& Manzon, M. (2007). Comparing Values. In M. Bray, B. Adamson \& M. Mason, Comparative education research. Approaches and methods (s. 259-285). Hong Kong: Springer.

Leung, F. K. S. \& Park, K. (2007). Comparing Educational Achievements. In M. Bray, B. Adamson, \& M. Mason, Comparative education research. Approaches and methods (s. 387-415). Hong Kong: Springer

Lor, P. (2011). International and comparative librarianship. Berlin: De Gruyter Saur.

Maddox, B. (2005). Assessing the impact of women's literacies in Bangladesh: An ethnographic inquiry. International Journal of Educational Development, 25(2), 123-132.

Manzon, M. (2007). Comparing places. In M. Bray, B. Adamson, \& M. Mason (Eds.), Comparative education research: Approaches and methods (s. 85-121). Hong Kong: Comparative education research centre, The University of Hong Kong. 
Mareš, J. (2013). Přehledové studie: jejich typologie, funkce a způsob vytváření. Pedagogická orientace, 23(4), 427-454.

Marginson, S., \& Mollis, M. (2001). The door opens and the tiger leaps: Theories and reflectivities of comparative education for a global millenium. Comparative Educational Review, 45(4), 581-615.

Marshall, J. (2014). Introduction to comparative and international education. Los Angeles: Sage.

Mason, M. (2007). Comparing Cultures. In M. Bray, B. Adamson, \& M. Mason, Comparative education research. Approaches and methods (s. 221-259). Hong Kong: Springer.

McNess, E. (2004). Culture, context and the quality of education: Evidence from a smallscale extended case study in England and Denmark. Compare: A Journal of Comparative Education, 34(3), 315-327.

Mortagy, Y., \& Boghikian-Whitby, S. (2010). A longitudinal comparative study of student perceptions in online education. Interdisciplinary Journal of E-Learning \& Learning Objects, 6, 23-44.

Moyles, R., \& Hargreaves, L. (1998). The primary curriculum: Learning from international perspectives. London: Psychology Press.

Musa, N., \& Agbaire Jomafuvwe, J. (2013). Methodological issues in comparative education studies? An exploration of the approaches of Kandel and Holmes. Journal of Educational Research, 6(3), 349-356.

Noah, H. J., \& Eckstein, M. A. (1970). Toward a science of comparative education. Comparative Education Review, 14(1), 103-105.

Pennings, P., Keman, H., \& Kleinnijenhuis, J. (1999). Doing research in political science. London: Sage.

Phillips, D. (2006). Comparative education: Method. Research in Comparative and International Education, 1(4), 304-319.

Phillips, D., \& Schweisfurth, M. (2008). Comparative and international education. An introduction to theory, method, and practice. London: Continuum.

Preston, R. (2001). Contextual and methodological influences on trends in comparative and international educational research. In K. Watson (Ed.), Doing comparative education research: Issues and problems (s. 69-84). Oxford: Symposium Books.

Průcha, J. (2006). Srovnávací pedagogika. Praha: Portál.

Průcha, J. (2015). Česká srovnávací pedagogika: přehled produktů let 1992-2012. In D. Greger (Ed.), Srovnávací pedagogika: proměny a výzvy (s. 39-58). Univerzita Karlova v Praze: Pedagogická fakulta.

Remmen, R., Scherpbier, A., Van Der Vleuten, C., Denekens, J., Derese, A., Hermann, I., ... Bossert, L. (2001). Effectiveness of basic clinical skills training programs: A cross-sectional comparison of four medical schools. Medical Education, 35, 121-128.

Rust, V. D. (2003). Method and methodology in comparative education. Comparative Education Review, 47(3), 86-109.

Rust, V. D., Johnstone, B., \& Allaf, C. (2009). Reflections on the development of comparative education. In R. Cowen \& A. M. Kazamias (Eds.), International handbook of comparative education (s. 121-138). London: Springer.

Rust, V. D., Soumaré, A., Pescador, O., \& Shibuya, M. (1999). Research strategies in comparative education. Comparative Education Review, 43(1), 86-109. 
Saeki, N., Xitao F., \& Lani, V. D. (2001). A comparative study of creative thinking of American and Japanese college students. The Journal of Creative Behavior, 35(1), 24-26.

Steiner-Khamsi, G. (2002). Reterritorializing educational import: Explorations into the politics of educational borrowing. In A. Nóvoa \& M. Lawn (Eds.), Fabricating Europe: The formation of an education space (s. 69-86). Dordrecht: Kluwer Academic.

Sweeting, A. (2005). The historical dimension: A contribution to conversation about theory and methods in comparative education. Comparative Education, 41(1), 25-44.

Theisen, G. \& Adams, D. (1990). Comparative Education Research. What are the methods and uses of comparative education research? In R. M. Thomas (Ed.), International comparative education. Practices, issues, prospects (s. 277-300). Oxford: Pergamon press.

Thomas, R. M. (1990). The nature of comparative education. How and why are education systems compared? In R. M. Thomas (Ed.), International comparative education. Practices, issues, prospects (s. 1-21). Oxford: Pergamon press.

Veenhoven, R. (2000). Freedom and happiness: A comparative study in forty-four nations in the early 1990's. In E. Diener \& M. Suh (Eds.), Culture and subjective well-being (s. 257-288). Massachusetts: MIT Press.

Vlček, P. (2015). Srovnávací výzkum v pedagogice - některé úvahy o metodologii problémového př́stupu. Pedagogická orientace, 25(3), 394-412.

Von Elek, T., \& Oskarsson, M. (1973). Teaching foreign language grammar to adults: A comparative study. Stockholm: Almquist \& Wiksell.

Walterová, E. (1993). Výzkum ve srovnávací a mezinárodní pedagogice a jeho funkce v transformaci vzdělávání. Pedagogika, 43(3), 379-384.

Walterová, E. (2006). Srovnávací pedagogika. Vývoj a proměny v globálním kontextu. Praha: Pedagogická fakulta Univerzity Karlovy.

Walterová, E. (2015). Proměny srovnávací pedagogiky v globální perspektivě. In D. Greger (Ed.), Srovnávací pedagogika: proměny a výzvy (s. 13-38). Univerzita Karlova v Praze: Pedagogická fakulta.

Watson, K. (2001). Doing comparative education research. Issues and problems. London: Symposium Books.

Watts, R. (1998). From lady teacher to professional: A case study of some of the first headteachers of girls' schools in England. Educational Management and Administration, 26(4), 339-351.

Winzer, M., \& Mazurek, K. (2012). Analyzing inclusive schooling for students with disabilities in international contexts: Outline of a model. Journal of International Special Needs Education, 15(1), 12-23.

Wiseman, A. W., \& Chase-Mayoral, A. (2013). Shifting the discourse on neo-institutional theory in comparative and international education. International Perspectives on Education and Society, 20, 99-126.

\section{Autorky}

prof. PhDr. Milada Rabušicová, Dr., Masarykova univerzita, Filozofická fakulta, Ústav pedagogických věd, Arna Nováka 1, Brno 603 00, e-mail: milada@phil.muni.cz

Mgr. Klára Záleská, Masarykova univerzita, Filozofická fakulta, Ústav pedagogických věd, Arna Nováka 1, Brno 603 00, e-mail: zaleska@phil.muni.cz 


\title{
Methodological issues in comparative education: Inspiration for designing comparative studies
}

\begin{abstract}
The aim of this paper is to discuss methodological approaches which have emerged in comparative education during its recent development and which are being currently used, in the form of a critical review. Authors have sought information primarily in the foreign literature over the last two decades. Methodological issues in comparative education are usually addressed through the following categories: purpose of comparative studies (description, analysis, explanation, prediction), research design (case studies, large-scale surveys), various theoretical and methodological approaches (plurality of methods and research techniques), models of comparison and the width and depth of comparative studies (local, regional, global), used sources (data collection, meta-analysis of existing data, documents), the role of researchers and finally methodological limits of comparative studies. The purpose of this paper is to provide a picture of possible options, which researchers could start with in designing their own comparative studies, in some cases also followed by examples of already existing comparative research studies.
\end{abstract}

Keywords: comparative education, purposes of comparative research, designs of comparative studies, case studies, large-scale surveys, methods of data collection, comparison approach, localization of cases

Průcha, J., Burkovičová, R., Dopita, M., Paloncyová, J., \& Syslová, Z. (2016). Předškolní dítě a svět vzdělávání. Přehled teorie, praxe a výzkumných poznat$k u ̊$. Praha: Wolters Kluwer.

Kniha si klade za cíl přispívat k rozvoji teorie a výzkumu vědecké disciplíny o předškolním vzdělávání. Zatímco předškolní vzdělávání má v českém prostředí rozvinutou praxi realizovanou různými institucemi, tato praxe nenachází dosud dostatečnou vědeckou reflexi. Předpokladem takové reflexe je rozvoj systematického a multidisciplinárně orientovaného výzkumu. Proto se jednotlivé části monografie zabývají nejprve teoretickými koncepcemi fenoménu dětství v různých vědách (psychologie, sociologie, antropologie aj.). Dále jsou popsány sociální, ekonomické a demografické charakteristiky dětské populace a je podán přehled současné realizace předškolního vzdělávání jak v České republice, tak v několika zemích Evropy a v USA. Podstatná část knihy je věnována zmapování zahraničního výzkumu předškolního vzdělávání, jeho trendů, metod a prrístupů, relevantních nálezů. Informativní účel má přehled zahraničních publikací, encyklopedií, časopisů, výzkumných center a vědeckých asociací v dané oblasti. 